\title{
The Negative Effects of Social Capital in Organizations: A Review and Extension
}

\author{
Kishore Gopalakrishna Pillai, Gerard P. Hodgkinson, ${ }^{1}$ \\ Gurumurthy Kalyanaram ${ }^{2,3}$ and Smitha R. Nair ${ }^{4}$ \\ Bradford University School of Management, Bradford, BD9 4JL, UK, ${ }^{1}$ Warwick Business School, University of \\ Warwick, Coventry, CV4 7AL, UK, ${ }^{2}$ City University of New York, USA, ${ }^{3}$ Tata Institute of Social Sciences, Mumbai, \\ India, and ${ }^{4}$ Sheffield University Management School, University of Sheffield, UK \\ Corresponding author email: Kgopala1@bradford.ac.uk
}

\begin{abstract}
Numerous studies have examined the positive effects of social capital in organizations, whereas the possible negative effects have attracted considerably less scholarly attention. To rectify this imbalance, this paper first undertakes a rigorous review of the published scholarly empirical evidence pertaining to the negative effects of social capital in organizations through a search of Web of Knowledge and Scopus, and then enumerates six potentially negative effects arising from increased levels of social capital. The review focuses on negative effects arising from bonding social capital and those arising from dense networks and closure, advancing new theory to elucidate the generative mechanisms that give rise to the proposed negative effects. Finally, the authors identify potential moderators of the negative effects thus theorized. Using the lens of social identification theory, the authors argue that dysfunctional identification processes restrict the processing of information and stimulate over-commitment to established relationships, diluting in turn the dialectical process, and inhibiting individual learning within organizations, culminating in groupthink, the postponement of structural adjustments, the non-rational escalation of commitment, and the blurring of firms' boundaries. This review thus furthers the agenda of a more balanced inquiry into the effects of social capital in organizations.
\end{abstract}

\section{Introduction}

The notion of social capital (SC), brought to prominence through the work of sociologists such as Bourdieu (1986) and Coleman (1988), has attracted significant scholarly attention in recent years. The core insight of this body of work is that networks of relationships and connections constitute an important resource for the conduct of social affairs (Burt 1997; Kostova and Roth 2003; Nahapiet and Ghoshal 1998; Portes 1998; Uzzi 1996), affording their members "collectivity-owned capital, a "credential" which entitles them to credit, in the

The authors thank Akbar Zaheer for helpful comments and suggestions on earlier versions of this paper.

[The article has been changed on 15 July 2016 since first publication.] various senses of the word' (Bourdieu 1986, p. 249). An impressive volume of evidence supports SC theory's central predictions (for recent overviews, see Kwon and Adler 2014; Lee 2009; Portes and Vickstrom 2011). Inter alia, higher levels of SC have been associated with: (a) greater career success and executive compensation (Belliveau et al. 1996), (b) knowledge access, inter-unit resource exchange and product innovation (Huggins 2010; Maurer et al. 2011; Pittaway et al. 2004; Tsai and Ghoshal 1998; Zheng 2010) and intellectual capital creation (Nahapiet and Ghoshal 1998), (c) the effectiveness of workgroups (Oh et al. 2004), and (d) superior managerial (Moran 2005) and organizational (Acquaah 2007; Batjargal 2003) performance.

These achievements notwithstanding, the central message of the present paper is that the contribution of SC theory to the analysis of behavior in 
organizations needs rethinking; for, in parallel to the above advances, scholars have also identified a number of potentially serious negative effects (see, e.g., Adler and Kwon 2002; Kwon and Adler 2014; Locke 1999). However, this antithetical work has lacked theoretical depth, relative to the substantial body of work examining the positive effects of SC. Accordingly, in this paper we set out to advance a more balanced account of SC, through a deeper consideration of its potential negative effects within and between organizations. Our analysis identifies six such effects, namely: (1) dilution of the dialectical process; (2) inhibition of individual learning; (3) groupthink; (4) postponement of structural adjustments; (5) non-rational escalation of commitment; and (6) blurring of firms' boundaries. We maintain that these negative effects arise from fundamental (dysfunctional) processes of social identification (Ashforth and Mael 1989), restricting in turn the processing of new information by directing attention inward to selected aspects of the information environment. Our analysis thus deepens understanding of the generative mechanisms underpinning the potentially deleterious consequences of $\mathrm{SC}$ for organizations and, in so doing, responds to recent calls to deepen understanding of the processes underpinning its development (Jordan and Munasib 2006).

For the purposes of this review, we adopt Inkpen and Tsang's (2005, p. 151) definition of SC: '[the] aggregate of resources embedded within, available through, and derived from, the network of relationships possessed by an individual or organization.' Within the confines of this definition, SC is characterized by a number of attributes, which, following Nahapiet and Ghoshal (1998), can be analyzed conveniently along three major dimensions, reflecting its structural, relational and cognitive properties. The structural dimension refers to the overall pattern of connections between a given group of actors (Nahapiet and Ghoshal 1998). The relational dimension, in contrast, distinguishes the varieties of personal relationships identified by researchers and consists of trust, reciprocity, expectations, and obligations (Lee 2009; Nahapiet and Ghoshal 1998; Tsai and Ghoshal 1998). The cognitive dimension differentiates the resources that variously provide, 'shared representations, interpretations, and systems of meaning among parties' (Nahapiet and Ghoshal 1998, p. 244). The bulk of recent work on SC in organization studies has been based on this three-dimensional conceptualization (see, e.g., Inkpen and Tsang 2005; Tsai and Ghoshal 1998).
Scholars addressing the structural dimension distinguish between the notions of closure (Coleman 1990) and structural holes (Burt 1992), highlighting, respectively, the value of close ties and interconnections among actors (often measured as network density) and the brokerage benefits derived from the bridging of gaps in the focal network. In a similar vein, Putnam (2000) distinguishes between bonding and bridging SC, the former referring to ties among actors who are members of the focal network, the latter to ties that interconnect actors from otherwise separate networks.

Recent research has sought to reconcile these differing views by demonstrating that the closure and structural holes perspectives are complementary, and the benefits arising from the membership of dense networks are enhanced in the context of seeking to bridge structural holes (Rost 2011). The present review, however, focuses on the negative effects arising from dense networks and closure. Hence, we do not address the structural holes perspective. In terms of Putnam's (2000) distinction between bridging and bonding SC, our focus is mainly on the latter. Higher levels of SC, as used subsequently in this paper, imply greater density and closure.

Prior research has documented evidence of a series of 'dark side' effects (e.g. Edelman et al. 2004; Locke 1999; Tura and Harmaakorpi 2005; Westlund and Bolton 2003) and several alternative perspectives, reviewed in the next section, have been advanced to account for them. Like Jordan and Munasib (2006), we maintain that the underlying processes that manifest these effects need better explication, and we further this agenda using the lens of social identification theory (Ashforth and Mael 1989).

Social identification is said to occur whenever actors internalize a particular social identity; it entails the perception of being psychologically intertwined with the fate of the pertinent social unit(s) (e.g. group, organization, profession, industry and/or country) with which the actor identifies (Ashforth and Mael 1989). Social identification promotes self-definition in terms of the social unit of identification (cf. Ashforth and Mael 1989). Identity researchers have conjectured that social identification can be thought of as a particularly potent form of SC (Haslam et al. 2003). Social capital theorists have observed that social identification is an important facet of relational SC (Nahapiet and Ghoshal 1998). Frequent interactions and being embedded in a dense, high-closure network can also facilitate identification processes (Ibarra et al. 2005). Potentially, therefore, all three 
dimensions of SC (structural, relational, and cognitive) are underpinned by social identification processes.

Social identification theory is an especially attractive lens through which to examine dark side effects, because it explicates clear bridging mechanisms that interconnect individuals and social structures (cf. Haslam et al. 2003; Jensen and Jetten 2015; Maghrabi et al. 2013), an issue that requires more attention in the SC literature (Ibarra et al. 2005; Kilduff and Krackhardt 1994). We maintain that social identification is the main generative mechanism that ties together the various negative effects highlighted in this review, directing actors' attention and restricting the processing and acceptance of potentially novel insights that would otherwise stymie those effects. Extant accounts have focused selectively on particular negative effects addressed in this review, treating them in a relatively superficial and disparate fashion rather than incorporating them into a more unified and integrated account of the sort attempted in the present paper.

\section{Reviewing the negative effects}

\section{Negative effects on economy and society}

Over the past two decades, a spate of scholarly papers in economics, psychology, sociology, and allied disciplines have examined the negative/dark side effects of SC on social and economic communities. In sociology, for example, McLean (2007/8), citing Putnam (2000), a political scientist, argues that bonding SC has the potential to exclude people who do not belong to particular social entities. Arneil (2006) notes similarly the role played by bridging SC in enabling dominant groups to protect their self-interests, while Andrist (2008) highlights the deleterious consequences of SC in general in accentuating restrictions on women and diminishing their autonomy (see also Ganapati 2013). At the country level, Yoo and Lee (2009) observe that low-trust societies such as Korea have recorded sound economic performance. Each of these developments points to the need for a re-examination of the basic premise of SC theory.

Social scientists and business and management scholars have advanced a range of perspectives in an attempt to account for SC's dark side effects on social and economic communities. Chief among these perspectives are Gabbay and Leenders's (1999) social liability argument, Grabher's (1993) cognitive lockin assertion, Westlund and Bolton's (2003) notion of the entrepreneurship inhibiting role played by SC,
Portes's (1998) blindness assertion, and Woolcock's (1998) homogeneous networking argument.

According to Gabbay and Leenders (1999), when a social structure impedes and restricts action, it becomes a social liability; in addition, negative ties in the prevailing social structure can limit opportunities. They thus caution that overinvestment in SC can result in negative returns.

Grabher (1993) studied the decline of the iron and coal industries in the Ruhr region in the 1970s and 1980s, finding that close linkages between firms in the area prevented the flow of useful outside information, resulting in a 'cognitive lock-in'; firms fell prey to established modes of thinking and doing. Adaptation and innovation were incremental and no one raised fundamental questions that would have highlighted the need for major, discontinuous innovation (see also Florida et al. 2002; Martinez and Aldrich 2011). In a similar vein, Westlund and Bolton (2003) argued that SC has an entrepreneurship inhibiting role, underscoring the need to diversify and reorganize regionbound SC, so that it can support innovation, through a balancing of strong and weak ties and internal and external links. Relatedly, Lee and Tuselmann (2013) provided empirical support for the claim that bonding SC can inhibit entrepreneurship and innovation. Similarly, Fazio and Lavecchia (2013) demonstrated empirically that path dependencies arising from 'proximity and trust' contribute to the formation of 'spatial traps', hindering regional economic development.

According to Portes (1998, p. 15), SC can yield four negative consequences: 'exclusion of outsiders, excess claims on group members, restrictions on individual freedoms, and downward leveling norms'. Woolcock (1998) notes that SC residing in homogeneous networks, such as those in the context of ethnic entrepreneurship (e.g. Koreans in Los Angeles), although beneficial during the early stages, helping new immigrants set up their businesses, can restrict the access of established network members to new networks and markets. Such restricted access, along with obligations to fellow network members, limits the growth of entrepreneurial ventures. Woolcock's analysis highlights the need for heterogeneity of connections in a given network, as a basis for mitigating these effects (see also Portes and Vickstrom 2011).

Supporting evidence for each of the foregoing arguments in this section has been amassed in a large body of empirical work, especially work on regional SC (Foley and Edwards 1999; Grootaert 2001; Krishna and Shrader 2000; Malecki 2012; Staber 
2007; Tura and Harmaakorpi 2005). The principal contribution of this body of work as a whole lies in highlighting a variety of interrelated negative consequences of SC accumulation for economy and society. However, as in the case of the growing body of work addressing SC's dark side effects in organizational settings, to which we now turn, the time is ripe for advancing a deeper understanding of the generative mechanisms underpinning those consequences.

\section{Negative effects in organizational settings}

In the organizational context, Locke (1999) identifies a number of potentially serious flaws in SC theory. Arguing that a loss of objectivity results from the linking of business and social relationships, he maintains that actors become deeply embedded in extant networks, resulting in the exclusion of potentially beneficial new actors and ideas; furthermore, current theory negates the role of the individual in the knowledge creation process. Locke also challenges the causal connection proposed by Nahapiet and Ghoshal (1998), whereby SC leads to intellectual capital. Rather, knowledge is discovered at the individual level, disseminated at the social level, and utilized and routinized at the organizational level (see also Edelman et al. 2004).

Adler and Kwon (2002) discuss the benefits and risks of SC. Distinguishing between risks for the focal actors and risks of negative externalities for the social network of which the focal firm is a constituent member, they identify major risks in respect of the focal actor. First, building SC requires investment that might not prove cost efficient. Second, the power benefits might trade off against the information benefits. Third, the solidarity benefits might embed actors tightly into particular relationships or sets of relationships, restricting in turn the free flow of new ideas and innovations that are generated beyond the network, resulting in inertia and parochialism.

In recent years, a growing number of scholars have examined empirically SC's negative effects in organizations. Table 1 summarizes the findings of studies documenting these dark side effects, based on a systematic search of the Web of Knowledge and Scopus databases. Our search was confined to papers appearing in the period 2000 to mid-2015 that incorporated 'social capital' in their titles. Using the Thomson Reuters Social Science Citation Index (SSCI), we only included empirical papers discussing the negative consequences of SC that had appeared in the top 45 journals, as ranked on the basis of the two-year impact factor in the 2011 business category. Several additional papers were included on the basis of a supplementary search using the Scopus database and peer recommendation (cf. Lee 2009). ${ }^{1}$

Our analysis reveals several interesting and important patterns. Multiple studies have examined the deleterious consequences of various forms of SC on seven key dependent variables, namely: (1) innovation (de Clercq et al. 2009; Edelman et al. 2004) and related processes of knowledge transfer and knowledge creation (Weber and Weber 2011); (2) knowledge acquisition (Presutti et al. 2007; YliRenko et al. 2001); (3) the development of dependence-oriented and inward-looking cultures (Eklinder-Frick et al. 2011, 2012; Gu et al. 2008; Warren et al. 2004); (4) inertia (Gargiulo and Benassi 2000; Maurer and Ebers 2006); (5) firm performance (e.g. Batjargal 2007; Godesiabois 2008; Malik 2012; Rouzies and Hulland 2014); (6) decision effectiveness (Jansen et al. 2011,2013; Li et al. 2013; Warren et al. 2004); and (7) internationalization strategy (Chetty and Agndal 2007; Lindstrand et al. 2011). A final group of studies, (8), addressed a wide range of miscellaneous problems, from the effects of social cohesion on the outcomes of open source software development projects (Singh et al. 2011), to the effects of social relationships on the value creation of firms (Molina-Morales and Martinez-Fernandez 2010), to the moderating effects of low absorptive capacity in accentuating the negative effects of SC on the IPO value of firms (Xiong and Bharadwaj 2011), among other topics. Each of the first seven topic categories contains multiple studies, spanning a diverse range of contexts and/or employing varying methods of data collection and analysis, whereas, with the notable exception of the two studies examining the impact of $\mathrm{SC}$ on the relative career progression of women and

\footnotetext{
${ }^{1}$ It is important to note that the present review, although extensive, does not purport to be comprehensive. Our initial searches were confined to papers appearing over the 20002012 period. However, in line with standard IJMR editorial policy, upon conditional acceptance with final minor revisions, we extended our search to incorporate the most relevant of those publications that had appeared more recently, thus ensuring that our review maintained its currency. To avoid 'an infinite regress', we undertook this final search employing the exact same search strategy as employed in our initial searches, save for the fact that we searched over the period 2013 to mid-2015. However, the majority of new papers thus identified engaged only superficially with the SC literature and/or focused on topics beyond the scope of the present review (for representative examples of excluded papers, see Ahearne et al. 2014; Sundaramurthy et al. 2014).
} 
Table 1. Summary of selected studies on the negative effects of social capital on key organizational processes and outcomes published between 2000 and 2015

\begin{tabular}{|c|c|c|c|c|}
\hline $\begin{array}{l}\text { Key themes and } \\
\text { authors }(\text { year of } \\
\text { publication) }\end{array}$ & Context/sample & Hypothesized mechanisms and effects & Major findings & $\begin{array}{l}\text { Contribution to } \\
\text { illuminating the } \\
\text { generative } \\
\text { mechanisms and } \\
\text { focal effects } \\
\text { addressed in the } \\
\text { present review }\end{array}$ \\
\hline \multicolumn{5}{|c|}{ Innovation and knowledge creation } \\
\hline $\begin{array}{l}\text { de Clercq, } \\
\text { Thongpapanl, and } \\
\text { Dimov (2009) }\end{array}$ & 232 Canadian firms & $\begin{array}{l}\text { Social interactions may amplify the negativity associated with } \\
\text { relationship conflict and escalate the problem. Trust can also } \\
\text { lead to less monitoring, and greater groupthink. Trust } \\
\text { impedes debate and constructive discussion and there is a } \\
\text { tendency to discount conflicting opinions. }\end{array}$ & $\begin{array}{l}\text { Social interactions strengthen the } \\
\text { negative relationship between } \\
\text { relationship conflict and } \\
\text { innovation. Trust weakens the } \\
\text { positive relationship between task } \\
\text { conflict andinnovation. }\end{array}$ & $\begin{array}{l}\text { Alludes to groupthink } \\
\text { and dilution of the } \\
\text { dialectical process. }\end{array}$ \\
\hline Edelman et al. (2004) & $\begin{array}{l}\text { Interviews with } 16 \text { managers } \\
\text { in two UK firms }\end{array}$ & $\begin{array}{l}\text { Organizational restructuring can leave holes in the network, } \\
\text { which hampers the effectiveness of social capital. Cognitive } \\
\text { social capital can create barriers between groups within the } \\
\text { organization, which hampers problem-solving and } \\
\text { innovation. Relational norms can create barriers for wider } \\
\text { knowledge dissemination within the organization. }\end{array}$ & $\begin{array}{l}\text { Social capital hinders } \\
\text { problem-solving, innovation, } \\
\text { creativity and knowledge } \\
\text { dissemination. }\end{array}$ & $\begin{array}{l}\text { Identification is } \\
\text { implied when the } \\
\text { barriers between } \\
\text { groups are } \\
\text { discussed. }\end{array}$ \\
\hline $\begin{array}{l}\text { Weber and Weber } \\
\text { (2011) }\end{array}$ & $\begin{array}{l}12 \text { corporate venture } \\
\text { capital triads in Germany }\end{array}$ & $\begin{array}{l}\text { Structural and personal lock-ins result in social liability. } \\
\text { Structural lock-ins lead to inflexibility and dependence. } \\
\text { Personal lock-ins can impede knowledge transfer and } \\
\text { innovation. }\end{array}$ & $\begin{array}{l}\text { Initially, social capital supports } \\
\text { knowledge transfer and creation; } \\
\text { but eventually, personal and } \\
\text { structural lock-ins transform it into } \\
\text { a liability. }\end{array}$ & N/A \\
\hline \multicolumn{5}{|l|}{ Knowledge acquisition } \\
\hline Presutti et al. (2007) & $\begin{array}{l}107 \text { small hi-tech firms in } \\
\text { Italy }\end{array}$ & $\begin{array}{l}\text { Over-embeddedness, and the consequent information } \\
\text { redundancy, can result in a negative relationship between } \\
\text { cognitive/relational social capital and knowledge acquisition. } \\
\text { When cognitive identification is high, monitoring diminishes, } \\
\text { and this hinders the acquisition of new knowledge. } \\
\text { Over-embeddedness also leads to an absence of structural } \\
\text { holes in the network, hindering the acquisition of new } \\
\text { knowledge. }\end{array}$ & $\begin{array}{l}\text { Relational and cognitive dimensions } \\
\text { of social capital are negatively } \\
\text { correlated with knowledge } \\
\text { acquisition. }\end{array}$ & $\begin{array}{l}\text { Brief mention of } \\
\text { identification as an } \\
\text { attribute of } \\
\text { cognitive social } \\
\text { capital. }\end{array}$ \\
\hline $\begin{array}{l}\text { Yli-Renko et al. } \\
\quad \text { (2001) }\end{array}$ & $\begin{array}{l}180 \text { hi-tech ventures in the } \\
\text { UK }\end{array}$ & $\begin{array}{l}\text { Relationship quality, a dimension of social capital, has a } \\
\text { negative effect on knowledge acquisition, arising from } \\
\text { over-embeddedness. Also, high trust lowers the need to }\end{array}$ & $\begin{array}{l}\text { Relationship quality in key customer } \\
\text { relationships negatively affects } \\
\text { knowledge acquisition. }\end{array}$ & N/A \\
\hline
\end{tabular}




\section{Dependence oriented/ inward looking culture}

\section{Study of a Swedish regional}

(2011, 2012) strategic network

Gu et al. (2008)

Senior managers in 282

Chinese firms

Warren et al. (2004)

Two studies in China among business school students (respective sample sizes $N$ $=203$ and $N=195$

\section{Inertia}

Gargiulo and Benassi (2000)

\section{Maurer and Ebers} (2006)
Data from a special unit in an Italian subsidiary of an $\mathrm{MNC}$ in the computing industry

\section{Longitudinal case studies of} six firms in the

biotechnology industry
Bonding creates a dependency-oriented culture and leads to low network mobility and inhibits the creation of new connections. Information flows beyond the focal network are restricted, resulting in failure to see networking as a marketing tool and creating a product focus.

Guanxi can lead to overembeddedness, hindering the flow of new ideas, and generating collective blind spots. Obligations to others in the network can be constricting and cost inefficient. The inward looking guanxi can be slow in accepting new members, resulting in lost opportunities with more capable partners.

In-group over-identification can result in several negative consequences for organizations, including obligations can be restricting and harmful; it excludes outgroups; also bribery, smuggling and tax evasion. At the societal level, it can lead to monopolies, lack of competition and lack of transparency.

Cohesive networks hinder adaptation; creating norms of reciprocity. These norms reduce opportunities to create and develop new relationships. Inertial forces can perpetuate ties that might have outlived their utility. Ties can also lead to cognitive lock-ins. Cohesiveness reduces the ability to adapt the structure and composition of the network, as required to respond effectively to changes in the task environment.

Inertia hinders adaptation to changing task and resource requirements. Social capital leads to rigidities that in turn become inertia. Rigidities arise from relational lock-in an cognitive lock-in. Obligations and norms of reciprocity constrain capacity and incentives for change. Intense interactions operate similarly. Shared identity and cognitive schemas limit learning and hinder the capability for change. Network density amplifies the negative effects thus theorized.
Bonding over-embeds actors (firms) within their social context leading inter alia to dependence-oriented

cultures, an internal product focus, and low network mobility.

Alludes to the dark side of Guanxi. In the context of technological turbulence and competitive intensity, Guanxi's positive effects weaken.

Several of the negative in-group effects hypothesized are

supported. Guanxi has negative effects both for specific member and for the network as a whole.

Cohesive networks lead to less adaptation of the network by managers to suit the changes in their roles, in turn reducing horizontal cooperation.

\section{Social capital needs adaptation.} When there is inertia, a firm's social capital can become liability.
N/A

Brief discussion of how relationship obligations and in-group identification can lead to negative outcomes observed.

N/A

Alludes to identification. 
Table 1. Continued

\begin{tabular}{|c|c|c|c|c|}
\hline $\begin{array}{l}\text { Key themes and } \\
\text { authors (year of } \\
\text { publication) }\end{array}$ & Context/sample & Hypothesized mechanisms and effects & Major findings & $\begin{array}{l}\text { Contribution to } \\
\text { illuminating the } \\
\text { generative } \\
\text { mechanisms and } \\
\text { focal effects } \\
\text { addressed in the } \\
\text { present review }\end{array}$ \\
\hline \multicolumn{5}{|l|}{ Firm performance } \\
\hline $\begin{array}{l}\text { Acquaah and } \\
\text { Appiah-Nkrumah } \\
\text { (2011) }\end{array}$ & Leading companies in Ghana & $\begin{array}{l}\text { Provides a resource based interpretation. Politicians can } \\
\text { demand favors (eg. employment of ill qualified people) } \\
\text { which will diminish firm performance. Firm-specific } \\
\text { managerial experience brings the abilities/competences to } \\
\text { utilize network resources to maximumadvantage. }\end{array}$ & $\begin{array}{l}\text { Social capital from politicians } \\
\text { negatively affects firm } \\
\text { performance. }\end{array}$ & N/A \\
\hline Batjargal (2007) & $\begin{array}{l}\text { Longitudinal study of } 94 \\
\text { internet ventures in China }\end{array}$ & $\begin{array}{l}\text { Habitual entrepreneurs are reluctant to exploit the opportunities } \\
\text { provided by bridging social capital. They fear that they will } \\
\text { be seen as manipulators. New entrepreneurs are less worried } \\
\text { about this concern. }\end{array}$ & $\begin{array}{l}\text { Interaction between start-up } \\
\text { experience of entrepreneurs and } \\
\text { the extent of their bridging social } \\
\text { capital negatively affects the } \\
\text { performance of the firm. }\end{array}$ & N/A \\
\hline Godesiabois (2008) & $\begin{array}{l}\text { Start-up venture capital (VC) } \\
\text { firms and theirco-investing } \\
\text { relationships with other } \\
\text { during the period } 1980- \\
2005\end{array}$ & $\begin{array}{l}\text { High embeddedness can lead to network closure effects, } \\
\text { resulting in the enforcement of group norms that will } \\
\text { constrain options available to the firm. }\end{array}$ & $\begin{array}{l}\text { Social capital, by constraining } \\
\text { options, negatively affects the } \\
\text { performance of new firms. }\end{array}$ & N/A \\
\hline Laursen et al. (2012) & 2000 Italian firms & $\begin{array}{l}\text { Overembeddedness can arise from too much social capital. } \\
\text { Identification of opportunities will be restricted to the local } \\
\text { environment. Higher levels of reciprocity and obligation also } \\
\text { will lead to a focus on local partners, thus restricting vision. } \\
\text { Environmental scanning becomes limited in scope. }\end{array}$ & $\begin{array}{l}\text { Localized potential social capital has } \\
\text { a curvilinear relationship } \\
\text { (inverted-U shaped) with } \\
\text { involvement in foreign markets. }\end{array}$ & N/A \\
\hline Malik (2012) & 252 pharmaceutical firms & $\begin{array}{l}\text { The quantity of ties matters more than the diversity of } \\
\text { information in explaining the negative relationship between } \\
\text { information diversity and performance. }\end{array}$ & $\begin{array}{l}\text { Information diversity, a dimension of } \\
\text { social capital, has a negative } \\
\text { relationship with firm } \\
\text { performance. }\end{array}$ & N/A \\
\hline $\begin{array}{l}\text { Rouzies and Hulland } \\
\text { (2014) }\end{array}$ & $\begin{array}{l}203 \text { employees in sales and } \\
\text { marketing from } 38 \text { US } \\
\text { firms in the consumer } \\
\text { packaged goods industry }\end{array}$ & $\begin{array}{l}\text { Hypothesized that higher degrees of customer concentration } \\
\text { will be associated with: a strengthening of the tie } \\
\text { strength-firm performance relationship; a strengthening of } \\
\text { the trust and cooperation-firm performance relationship; and } \\
\text { a weakening of the shared vision-firm performance } \\
\text { relationship. }\end{array}$ & $\begin{array}{l}\text { Social capital can inhibit a firm's } \\
\text { performance, depending on the } \\
\text { extent to which its customers are } \\
\text { concentrated, such that greater } \\
\text { concentration levels will attenuate } \\
\text { the relationship between cognitive } \\
\text { social capital and performance. }\end{array}$ & N/A \\
\hline
\end{tabular}


Stam and Elfring (2008)

90 new ventures

Villena et al. (2011)

132 Spanish firms

Yu and Chiu (2010)

Decision effectiveness Jansen et al. (2011)

Firms belonging to the electronics industry in Taiwan

434 strategic decisions in

Dutch service sector SMEs

Jansen et al. (2013)

\section{Dutch small-business} owners, spanning 7 sectors
Lack of access to novel information and pressure to conform to the norms and practices prevailing undermines organizational performance.

Social capital can lead to rigidities. Groupthink is possible, owing to a lack of challenging questions. Strong ties can lead to less monitoring, resulting in supplier opportunism. Strong ties create obligations and norms of reciprocity that lead to suboptimal decisions.

At very high levels of social capital, the cost of maintaining networks become high and might not yield returns; less flexibility to form new network connections.

The role of social capital as a decision aid. When the variety of connections is large, this can lead to gridlock. Evaluative judgments such as risk acceptance and confidence mediate, and in turn explain, the negative impact of social capital on decision effectiveness.

Further clarifies the role of social capital in strategic decision making in SMEs, from an information processing perspective. Network centrality can become a
liability. When bridging ties are few, centrality attenuates the entrepreneurial

orientation-performance relationship.

Social capital has an inverted curvilinear relationship with performance, in buyer-supplier interactions.

Social capital has an inverted-U shaped relationship with firm level performance.

Social capital undermines decision effectiveness in the manner hypothesized.

There is a trade-off between the level of central decision makers' experience and breadth of social capital in realizing decision effectiveness, such that either or both of these variables can be an asset or liability in respect of information processing efficiency and effectiveness, dependent on the extent to which the parties involved in implementation of the decision at hand are internally or externally based. When experience is an asset, breadth of social capital is a liability and vice versa.
Brief mention of groupthink and the dilution of dialectical process

\section{N/A}


Table 1. Continued

\begin{tabular}{|c|c|c|c|c|}
\hline $\begin{array}{l}\text { Key themes and } \\
\text { authors (year of } \\
\text { publication) }\end{array}$ & Context/sample & Hypothesized mechanisms and effects & Major findings & $\begin{array}{l}\text { Contribution to } \\
\text { illuminating the } \\
\text { generative } \\
\text { mechanisms and } \\
\text { focal effects } \\
\text { addressed in the } \\
\text { present review }\end{array}$ \\
\hline Li et al. (2013) & $\begin{array}{l}\text { Data gathered on the advice } \\
\text { networks of } 158 \\
\text { entrepreneurs in the } \\
\text { high-technology industry } \\
\text { in mainland China }\end{array}$ & $\begin{array}{l}\text { Empirical examination of the role of in-group identification in } \\
\text { increasing the strength of ties, which in turn constrain } \\
\text { decision making by promoting 'shared cognition', thereby } \\
\text { inhibiting new business development. }\end{array}$ & $\begin{array}{l}\text { In line with expectations, tie strength } \\
\text { correlates positively with decision } \\
\text { making constraint, which in turn } \\
\text { hinders new business development. }\end{array}$ & $\begin{array}{l}\text { Drawing on } \\
\text { self-categorization } \\
\text { theory, social } \\
\text { identification is } \\
\text { posited as a } \\
\text { mechanism } \\
\text { underpinning the } \\
\text { motivation of } \\
\text { entrepreneurs to } \\
\text { strengthen their ties } \\
\text { with fellow network } \\
\text { members. }\end{array}$ \\
\hline Warren et al. (2004) & See above & $\begin{array}{l}\text { In addition to the effects noted above, in-group } \\
\text { over-identification leads to suboptimal decision making. }\end{array}$ & $\begin{array}{l}\text { Empirical support for the effect } \\
\text { predicted. }\end{array}$ & $\begin{array}{l}\text { As noted above, brief } \\
\text { discussion of } \\
\text { in-group } \\
\text { identification. }\end{array}$ \\
\hline \multicolumn{5}{|l|}{ Internationalization } \\
\hline $\begin{array}{l}\text { Chetty and Agndal } \\
\text { (2007) }\end{array}$ & $\begin{array}{l}\text { Qualitative study of } 36 \\
\text { internationalization mode } \\
\text { changes }\end{array}$ & $\begin{array}{l}\text { Overembeddedness and feelings of obligations. Relationships } \\
\text { are costly to maintain. Lack of commitment and opportunistic } \\
\text { behavior of close partners render social capital a liability. }\end{array}$ & $\begin{array}{l}\text { Social capital liability influences } \\
\text { changes in internationalization } \\
\text { mode. }\end{array}$ & N/A \\
\hline $\begin{array}{l}\text { Lindstrand et al. } \\
\quad \text { (2011) }\end{array}$ & $\begin{array}{l}\text { Longitudinal cross-case study } \\
\text { of } 14 \text { Swedish biotech } \\
\text { SMEs }\end{array}$ & $\begin{array}{l}\text { Primarily a structural analysis, which identifies negative effects } \\
\text { that can be overcome by developing relational and cognitive } \\
\text { social capital. }\end{array}$ & $\begin{array}{l}\text { Social capital facilitates rapid } \\
\text { industrialization; however, it can } \\
\text { also hinder the development of } \\
\text { firms' understanding of foreign } \\
\text { markets. }\end{array}$ & N/A \\
\hline \multicolumn{5}{|l|}{ Miscellaneous } \\
\hline Collins (2006) & $\begin{array}{l}\text { Joint ventures among S\&P } \\
500 \text { firms }\end{array}$ & $\begin{array}{l}\text { Social capital generates behavioral expectations, which detract } \\
\text { from the quality of decision making of the focal firm. } \\
\text { Reciprocity is the main behavioral expectation that causes } \\
\text { the negative outcome. }\end{array}$ & $\begin{array}{l}\text { Firms with strong ties within their } \\
\text { network of joint ventures are more } \\
\text { likely to engage in undesirable } \\
\text { behaviors. }\end{array}$ & N/A \\
\hline
\end{tabular}


Table 1. Continued

\begin{tabular}{|c|c|c|c|c|}
\hline $\begin{array}{l}\text { Key themes and } \\
\text { authors (year of } \\
\text { publication) }\end{array}$ & Context/sample & Hypothesized mechanisms and effects & Major findings & $\begin{array}{l}\text { Contribution to } \\
\text { illuminating the } \\
\text { generative } \\
\text { mechanisms and } \\
\text { focal effects } \\
\text { addressed in the } \\
\text { present review }\end{array}$ \\
\hline $\begin{array}{l}\text { Grugulis and } \\
\text { Stoyanova (2012) }\end{array}$ & $\begin{array}{l}\text { Qualitative research in the } \\
\text { context of UK TV and film } \\
\text { industry }\end{array}$ & $\begin{array}{l}\text { Social capital can discriminate against outgroup members, } \\
\text { making it harder for minorities and women to secure jobs. } \\
\text { These effects are stronger in less structured environments } \\
\text { such as film and TV. }\end{array}$ & $\begin{array}{l}\text { Social capital confines advantages to } \\
\text { members of the network and } \\
\text { creates barriers and disadvantages } \\
\text { for non-members. }\end{array}$ & $\begin{array}{l}\text { Identification is } \\
\text { implied when } \\
\text { in-groups and } \\
\text { outgroups are } \\
\text { discussed. }\end{array}$ \\
\hline Luk et al. (2008) & $\begin{array}{l}189 \text { Chinese firms and } 203 \\
\text { firms from Hong Kong }\end{array}$ & $\begin{array}{l}\text { Institutional theory based arguments. Social capital has } \\
\text { properties of a 'club good'. It favors the in-group, } \\
\text { irrespective of its capabilities. This process is malignant as it } \\
\text { fosters specific and particularized trust, leading in turn to } \\
\text { social inequality. It is thus harmful to the society at large. }\end{array}$ & $\begin{array}{l}\text { Evidence of malignant effects of } \\
\text { social capital in a transition } \\
\text { economy. }\end{array}$ & N/A \\
\hline Lutter (2015) & $\begin{array}{l}\text { Quantitative analysis of a } \\
\text { large-scale longitudinal } \\
\text { dataset (1929-2010) } \\
\text { pertaining to the career } \\
\text { profiles of ca. } 1 \text { million } \\
\text { performances by } 97,657 \\
\text { film actors in the US film } \\
\text { industry, spanning } 369,099 \\
\text { film productions }\end{array}$ & $\begin{array}{l}\text { Argues that, when collaborating in cohesive teams, women } \\
\text { incur a 'closure penalty', resulting in severe deleterious } \\
\text { consequences for their careers. However, gender } \\
\text { disadvantages are attenuated for women who build social } \\
\text { capital in open networks with greater diversity and } \\
\text { information flows. }\end{array}$ & $\begin{array}{l}\text { Analysis of career survival models } \\
\text { and interaction effects between } \\
\text { gender and various indicators of } \\
\text { social capital and information } \\
\text { openness support the basic } \\
\text { predictions, thus illuminating the } \\
\text { boundary conditions under which } \\
\text { particular types of social capital } \\
\text { exacerbate or constrain gender } \\
\text { differences in career advancement. }\end{array}$ & $\begin{array}{l}\text { Alludes to gender } \\
\text { homophilous } \\
\text { networks as identity } \\
\text { networks that } \\
\text { undermine the } \\
\text { position power of } \\
\text { females relative to } \\
\text { their male } \\
\text { counterparts. }\end{array}$ \\
\hline $\begin{array}{l}\text { Molina-Morales and } \\
\text { Martinez- } \\
\text { Fernandez } \\
\text { (2010) }\end{array}$ & 154 Spanish firms & $\begin{array}{l}\text { Maintaining relationships is costly, reducing flexibility and } \\
\text { creating lock-in. Also, firms with high levels of trust will } \\
\text { have fewer new employees, will be set in their routines, and } \\
\text { prone tocomplacency. }\end{array}$ & $\begin{array}{l}\text { The intensity of social interactions } \\
\text { and the level of trust have } \\
\text { inverted-U shaped relationships } \\
\text { with firm level valuecreation. }\end{array}$ & N/A \\
\hline Pollock (2004) & US IPOs in 1992 & $\begin{array}{l}\text { Lead underwriters occupy structural holes. Theirembeddedness } \\
\text { can affect their ability to manage IPO prices. When the } \\
\text { conditions are good (i.e. demand is high) underwriters might } \\
\text { repay prior favors, thus leading to underpricing (increased }\end{array}$ & $\begin{array}{l}\text { Underwriters' embeddedness in } \\
\text { networks of institutionalinvestors } \\
\text { leads to underpricing, when the } \\
\text { demand for the IPO is high. }\end{array}$ & N/A \\
\hline
\end{tabular}


Table 1. Continued

\begin{tabular}{|c|c|c|c|c|}
\hline $\begin{array}{l}\text { Key themes and } \\
\text { authors (year of } \\
\text { publication) }\end{array}$ & Context/sample & Hypothesized mechanisms and effects & Major findings & $\begin{array}{l}\text { Contribution to } \\
\text { illuminating the } \\
\text { generative } \\
\text { mechanisms and } \\
\text { focal effects } \\
\text { addressed in the } \\
\text { present review }\end{array}$ \\
\hline Singh et al. (2011) & $\begin{array}{l}\text { Longitudinal panel study of } \\
2378 \text { projects hosted at } \\
\text { SourceForge }\end{array}$ & $\begin{array}{l}\text { Too much internal cohesion can foster convergent thinking and } \\
\text { overlooking of information that runs contrary to extant } \\
\text { thought. Too much external cohesion can lead to information } \\
\text { redundancy and discounting of information that goes against } \\
\text { current thinking. Too much technological diversity of } \\
\text { contacts can lead to difficulty in absorbing unfamiliar } \\
\text { knowledge. }\end{array}$ & $\begin{array}{l}\text { The relationship between external } \\
\text { cohesion (cohesion among } \\
\text { external contacts) and project } \\
\text { success is an inverted-U shaped } \\
\text { function. Moderate levels of } \\
\text { external cohesion are associated } \\
\text { with success. }\end{array}$ & $\begin{array}{l}\text { Allusions to } \\
\text { groupthink. }\end{array}$ \\
\hline Xiao and Tsui (2007) & $\begin{array}{l}417 \text { managers from four } \\
\text { Chinese companies }\end{array}$ & $\begin{array}{l}\text { Occupying structural holes and the consequent unclear group } \\
\text { membership attracts disapproval; disadvantageous in a } \\
\text { collectivist culture. This effect is more pronounced in high } \\
\text { commitment organizations. Strong identification promotes } \\
\text { cooperative behaviour. }\end{array}$ & $\begin{array}{l}\text { Structural holes can be detrimental to } \\
\text { employee rewards (salaries) }\end{array}$ & $\begin{array}{l}\text { Brief mention of } \\
\text { identification, i.e. } \\
\text { not discussed in } \\
\text { depth. }\end{array}$ \\
\hline $\begin{array}{l}\text { Xiong and Bharadwaj } \\
\text { (2011) }\end{array}$ & 177 IPOs & $\begin{array}{l}\text { Relationships have a financially constraining effect, which can } \\
\text { lead to the leakage of strategically important knowledge. } \\
\text { Young firms can become dependent on alliance partners, } \\
\text { which will inhibit their capability development. Focusing on } \\
\text { relationships with a few key customers can limit the firm's } \\
\text { vision and impede its competitive advantage. }\end{array}$ & $\begin{array}{l}\text { In the absence of appropriate } \\
\text { absorptive capacity, marketing and } \\
\text { R\&D B to B relationships have a } \\
\text { negative financial consequence } \\
\text { (IPO value). }\end{array}$ & N/A \\
\hline
\end{tabular}

aStudies are listed alphabetically within each theme on the basis of authorship. 
men (Grugulis and Stoyanova 2012; Lutter 2015), the topics addressed by the work summarized within the miscellaneous category comprise a series of standalone studies. These variations limit researchers' ability to reach accumulated generalizable conclusions from the work encapsulated in each category.

In total, nine studies have addressed the negative effects of SC on the performance of firms. Contrary to conventional wisdom (cf. Nahapiet and Ghoshal 1998), three of these studies (Acquaah and AppiahNkrumah 2011; Godesiabois 2008; Malik 2012) have observed statistically significant linear negative relationships, while three other studies (Laursen et al. 2012; Villena et al. 2011; Yu and Chiu 2010) have identified inverted-U-shaped relationships between $\mathrm{SC}$ and performance; that is, SC is beneficial initially, but after exceeding some threshold level, it acts as a constraining and restricting force. The remaining three studies (Batjargal 2007; Rouzies and Hulland 2014; Stam and Elfring 2008) have observed significant moderating/interactive effects of particular aspects of SC on firm-level performance. In short, there is a great deal of variation of findings across what is clearly a small number of studies. The range of explanations posited for this diversity of findings is similarly varied, as is the range of contexts in which the studies were undertaken. Among the mechanisms that might account for this general unexpected series of results are overembeddedness (Laursen et al. 2012), cost efficiency (Molina-Morales and Martinez-Fernandez 2010; Yu and Chiu 2010), inflexibility and lockin (Molina-Morales and Martinez-Fernandez 2010; Villena et al. 2011; Yu and Chiu 2010), and obligations and norms of reciprocity (Villena et al. 2011).

A similar confounding of context, methods and mechanisms plagues the studies falling within the other thematic categories, supporting our contention that it is difficult to reach meaningful accumulative conclusions, given the piecemeal and fragmented nature of the literature as a whole. Further illustrating the validity of this assertion, just three studies have examined the negative effects of SC on innovation (de Clercq et al. 2009; Edelman et al. 2004) and related processes of knowledge transfer and knowledge creation (Weber and Weber 2011). Although the findings of this work overall reinforce the concerns raised by Adler and Kwon (2002) that SC might restrict new ideas, thereby inhibiting innovation, as possible generative mechanisms, de Clercq et al. (2009) discuss the potentially inhibiting role of excessive trust on constructive dialogue as a precursor to group- think and the potentially amplifying role of social interaction on relationship conflict problems, whereas Edelman et al.'s (2004) analysis focuses on how dysfunctional intergroup processes arising from high levels of SC can serve as barriers to innovation. Weber and Weber (2011), in contrast, focus on the lock-in effects of SC on knowledge creation. Compounding these divergent foci, each study took place in a different country (Canada, the UK, and Germany, respectively), with marked variations in the number of participating firms across the three studies.

The above limitations point to the need for an overarching theoretical framework that pulls together the differing strands of empirical work summarized in Table 1 into a coherent whole. Several of the arguments advanced by Locke (1999) and Adler and Kwon (2002) coalesce around the notion that excessive SC can lead to a narrowing of attention and thus restrict access to new ideas. In addition, over-embeddedness and high levels of bonding SC are associated with over-commitment to, and over-identification with, established relationships, resulting in structural and cognitive lock-ins, inflexibility, and limited adaptation. As shown in Table 1, the empirical literature provides support for each of these lines of reasoning. It has been found that over-embeddedness reduces the flow of new ideas into the group, resulting in parochialism and inertia (Gargiulo and Benassi 1999). Powell and Smith-Doerr (1994, p. 393) capture this succinctly as follows: 'the ties that bind may also turn into the ties that blind.' It has also been found that cohesive networks lead to less adaptation (Gargiulo and Benassi 2000) and create a dependence-oriented culture (Eklinder-Frick et al. 2011).

Based on the studies outlined in Table 1, it can be seen that prior research has documented the roles of SC in limiting access to new information (resulting in structural and cognitive lock-ins and inflexibility) and restricting adaptation. An important theoretical omission, however, is the question as to how SC limits information processing and restricts adaptation and, in so doing, generates the deleterious outcomes alluded to at the outset. Although scholars have sought to examine this issue (Gargiulo and Benassi 2000; Maurer and Ebers 2006), as outlined in the final column of Table 1, identification processes have attracted only limited attention to date in explaining the negative effects of $\mathrm{SC}$, a surprising revelation, not least because, as indicated above, identification is arguably a fundamental process that is central to all three dimensions of SC. 
In sum, a thorough consideration of identification processes has been missing from the literature pertaining to the negative effects of SC in organizational contexts. The remainder of the present paper contributes to this endeavor by delineating the role of identification in generating six major negative effects. Two of these effects, dilution of dialectical process and groupthink, have attracted some attention in the SC literature to date (de Clercq et al. 2009; Villena et al. 2011). Our analysis deepens theoretical understanding of how these particular effects (and the four additional negative effects not considered hitherto) likely operate.

\section{Theorizing the negative effects}

At the intra-organizational level, we maintain that information restriction, as a function of social identification processes, inhibits individual learning, diluting in turn the intra-organizational dialectical process, thereby inhibiting collective level learning, and, potentially, fueling groupthink. At the organizational level, these dysfunctional effects can result in the postponement of necessary structural adjustments and fuel the non-rational escalation of commitment to failing courses of action. These dark-side effects of social identification can also be observed at the interorganizational level, although the effect sizes are probably weaker. Finally, also at the interorganizational level, social identification can lead to a blurring of firms' boundaries. Our multilayered account, centered on social identification processes, thus links these various effects.

\section{Dilution of the dialectical process}

Knowledge-based theories of the firm (e.g. Nonaka and Takeuchi 1995; Spender 1996) are predicated on the assumption that knowledge creation is a dynamic, dialectical process, wherein knowledge emerges by reconciling contradictions (Nonaka and Toyama 2002). Organizational knowledge creation is based on the conversion of tacit knowledge into explicit knowledge, though some commentators disagree on this aspect of the argument (cf. Hodgkinson 2003; Tsoukas 2003). Other researchers similarly conceive organizational learning, a process related closely to organizational knowledge creation, as a process that occurs when attempting to resolve the tensions between actors' conflicting social worlds that inevitably arise in the workplace (Elkjaer 2005; Elkjaer and Huysman 2008).
Social capital, via social identification processes (i.e. primarily cognitive SC), constrains the clash between thesis and antithesis, promoting an adherence to extant collective belief systems, legitimated through authority structures within the organization. Structural SC that leads to cohesiveness and hinders the flow of information emanating from beyond the group (Wasserman and Faust 1994) and relational SC that engenders norms of obligation, commitment, and reciprocity (Nahapiet and Ghoshal 1998; Villena et al. 2011) can also promote adherence to extant belief systems. In so doing, SC, in general, acts as a constraint upon individuals. This argument finds support in Durkheim's ([1895] 1938) work, according to which 'social facts' (including collective representations) are experienced by individuals as constraints. Durkheim ([1902-03] 1961) compared these social constraints to walls, molds or containers that keep gas from expanding in a vacuum. Martin (2002) employs this notion of constraint to measure the properties of a given belief system. When there is no constraint, individuals are free to believe anything they want, and no one set of beliefs is more or less probable than another. As Martin (2002) points out, this Durkheimian vision implies that a constraint constitutes any concentration among the points representing individual beliefs in the space of all possible beliefs. Such concentrations arise from the fact that the arbitrary movement of individuals within the belief space has been reined in through a social process.

We employ this imagery to represent the set of beliefs held by individuals within a given organization or network. Our argument is that SC essentially functions as a constraint by imparting order and structure to the distribution of beliefs. As Cornelissen et al. (2007) note, a shared sense of group membership with another person promotes an 'expectation of agreement' with that person on issues that are relevant to their shared identity, motivating the parties to persevere to reach such agreement and coordinate their behavior with reference to the issues at hand. Hence, $\mathrm{SC}$ leads to a concentration of points in the wider space of beliefs. Thesis and antithesis, the necessary conditions for synthesis, are found more easily in a formless distribution than in an ordered distribution. Hence, we maintain that, when actors over-identify with their network partners, SC hampers synthesis by impeding the generation of antitheses.

Network theorists have pointed out how interpersonal networks can, over time, produce strong norms and mutual identification among network members, limiting openness to new information 
and diverse views (Ibarra et al. 2005; Nahapiet and Ghoshal 1998). Researchers have also documented how social identification leads to group polarization, which means that group norms are perceived as more stereotypically extreme (Mackie 1986). We infer that such polarization will lead to pressure to conform to the opinions of prototypical members of the group or network, an assertion supported by the finding that less powerful individuals in organizations are likely to feel pressure to accept the perspectives and viewpoints of individuals who are more powerful (Walker 1985). The proximity effect, whereby network interactions influence perceptions, also leads to a similar dynamic (Ibarra and Andrews 1993).

The foregoing arguments point to the conclusion that SC experienced as constraints imposes structure on thoughts and beliefs (theses), which, in turn, prevent the generation of antitheses, a necessary condition for syntheses. Social information processing theorists have emphasized that the beliefs of significant others are especially likely to influence focal individuals' attitudes (Salancik and Pfeffer 1978). It follows from this view that SC is likely to accentuate the deleterious selective processing effects of identification, in turn inhibiting the development of counterfactual thinking.

Beliefs are also socially influenced through shared sensemaking processes (Gioia 1986), which involve developing an understanding of shared events through interaction among team members (Daft and Weick 1984). On the basis of this body of work as a whole, we reason that a significant danger posed by greater levels of SC is the fueling of confirmation bias (Jonas et al. 2001). The structure imposed on beliefs by SC arising from membership of dense networks will inhibit the generation of counterfactual perspectives, antithesis generation will suffer, and the dialectical process will be impeded.

The above line of reasoning extends to interorganizational contexts (cf. Abrahamson and Fombrun 1994; Hodgkinson and Healey 2011a, 2011b, 2014; Lant and Phelps 1999; Peteraf and Shanley 1997; Spender 1989). In times of increasing turbulence, navigating through dynamic environments requires the generation of new ideas often at odds with the received wisdom prevailing, and their reconciliation with existing modes of thought and established practices, so that viable new strategies are developed. The role of SC in hampering this process is, we maintain, particularly consequential in dynamic environments.

\section{Inhibition of individual learning within organizations}

Closely allied to the role played by high levels of $\mathrm{SC}$ in diluting the dialectical process is its role in inhibiting individual learning within organizations.

The rationale for this assertion is based on social learning theory, an important theoretical anchor for explaining learning in organizations (Bandura 1986; Wood and Bandura 1989). According to this theory, social interactions constitute an important mechanism through which actors, as learning social beings, construct their understanding (Elkjaer 2003). Within organizations, actors continuously engage in sensemaking and, in so doing, create knowledge

(Weick 1995). However, they do not learn solely through direct participation. They also learn vicariously by observing and then modeling the behavior of significant others, whose actions are variously rewarded and/or negatively reinforced (Bandura 1986).

Hence, social imitation is an important aspect of social learning, distinguishing it from trial-and-error

learning (Elkjaer 2003). The individual in social learning theory is a participant, both active and passive, in the social processes that constitute the everyday life of the organization. The organization provides the context and occasions for participants to interpret what is going on; in other words, the raw materials of knowledge creation (Elkjaer 2003; Richter 1998).

It follows from the social learning perspective that, as actors become more deeply embedded in the extant social networks of their organizations, the extent to which they are exposed to new sources of information and ideas will diminish, thus limiting opportunities for learning. This claim finds support in the work of Nicolini and Meznar (1995), who argue that organizational members situated at the periphery of the organization may learn faster than members at its core. Peripheral members are socialized and embedded into the collective knowledge and belief systems of the focal organization less completely; hence, they are more likely to appreciate the learning processes and sensemaking of adjacent communities, ones with divergent perspectives (DeFillippi and Ornstein 2003). This argument resonates with the notion of learning as a situated activity (Lave and Wenger 1991), according to which the situated nature of learning operates through a process known as 'legitimate peripheral participation'. This notion captures the interactions between newcomers and old timers, and the mechanism through which newcomers become incorporated into established communities of practice. Newcomers 
situated at the periphery of dense social networks enable learning because, not having been socialized into the ways and modes of the community of practice, and thus being less ensconced in its prevailing dominant logic, they are more likely to see myopia in others and bring in fresh insights that are antithetical to the status quo views of established participants (Hodgkinson and Healey 2011a; Hodgkinson and Sparrow 2002), thereby rejuvenating the dialectical process outlined in the previous section.

As noted earlier, through the proximity effect, whereby network interactions influence the perceptions of actors in close proximity (Ibarra and Andrews 1993), the dominant members of the network (i.e. actors with greater power, occupying centralized positions) can generate consensus throughout the network as a whole (Ibarra et al. 2005), not least because the less powerful members will probably feel pressure to accept the views of their more powerful counterparts (Walker 1985). The likely net effect of this process is that discrepant information will be discounted, thus limiting opportunities to learn. Scholars have noted that how individuals interpret issues affects their choices pertaining to the access of network resources (Bridwell-Mitchell and Lant 2014). Here, too, excessively high levels of SC can lead to homogenization in the interpretation and utilization of resources, thereby impeding learning.

The foregoing analysis highlights the ways in which identification, in inhibiting learning in organizations, is structural, cognitive, and relational in nature, thus lending additional credence to our earlier claim that the generative effects of identification pertain to all three dimensions of SC. In addition to inhibiting learning by reducing exposure to divergent viewpoints, an excess of SC inhibits learning by creating conditions inimical to critical questioning. According to Argyris (1994), learning occurs in two forms: single loop and double loop. Single-loop learning relies on simple, one-dimensional questions to elicit one-dimensional answers, whereas double-loop learning seeks to question the questioner. It asks questions about objective facts, but also probes the reasons and motives behind those facts. The mechanisms that inhibit double-loop learning are both social and psychological.

Previous research has documented that social identification leads to social cohesiveness (Scott 1997) and preferential treatment of in-group members (Tajfel and Turner 1979, 1986) and more helpful (prosocial) behaviors (Ashforth and Mael 1989). However, when taken to excess (i.e. when social iden- tification leads to an excess of cohesion and helpfulness), managers will probably avoid the deeper questioning essential for learning, but which also creates problems and discomfort within the organization. In so doing, they deprive employees and themselves of the opportunity to take responsibility for their own behavior by striving to understand it (Argyris 1994). Hence, social identification, by strengthening the process of avoiding uncomfortable questions out of consideration for others, constrains double-loop learning. In so doing, like dilution of dialectical process, discussed in the previous section, it provides the antecedent conditions that give rise to groupthink.

\section{Groupthink}

Groupthink refers to, 'a mode of thinking that people engage in when they are deeply involved in a cohesive in-group, when the members' striving for unanimity overrides their motivation to realistically appraise alternative courses of action . . . a deterioration of mental efficiency, reality testing and moral judgment that results from in-group pressures' (Janis 1972, p. 9). According to Janis $(1972,1982)$, groups experiencing groupthink reach poor decisions as a result of a strong concurrence-seeking tendency that suppresses critical inquiry. Groupthink results typically in an incomplete survey of the objectives at hand, poor information search, a limited discussion of too few alternatives, and a failure to examine the significant costs and risks of the alternatives preferred.

Certain antecedent factors are likely to increase the probability that groupthink will occur, not least group insulation, group homogeneity, high personal stress, overestimation of the group, closed mindedness, pressures towards uniformity, short time constraints, recent failure, the lack of a tradition of impartial leadership, and the lack of a tradition of methodical procedures (Janis 1982). These factors lead to information processing errors such as the ones described earlier, thus lowering the probability of favorable decision outcomes.

Increased SC, primarily relational and cognitive, is related to five of the antecedent factors described above. First, as argued earlier, SC, through the mechanism of social identification, imposes constraints on the thought space at hand and, in so doing, generates pressure toward a uniformity of beliefs.

Secondly, research has documented that identity at the functional unit level is enhanced by similarity of group members in terms of their education, training, and goal orientations (Byrne 1971; Kramer 1998). 
Scott (1997) found that social identification of team members is negatively related to functional diversity. It follows that social identification, and as a consequence $\mathrm{SC}$, is related to group homogeneity, one of the most significant antecedents of groupthink.

Thirdly, although bonding SC can promote the free flow of redundant information within networks (Tsai and Ghoshal 1998), as argued earlier, it also restricts the inflow of new information and ideas. Consequently, as bonding SC increases, the network will become more insulated as an information processing unit. Bonding SC also promotes concurrence seeking with prototypical members, limiting openness to outside information, thereby propelling the group toward a closed mindset (Woolcock 1998). Finally, as noted earlier, SC, through identification, leads to the polarization of group beliefs (Mackie 1986), which in turn leads members to overestimate the powers of the group. Especially in the context of other antecedent factors such as recent failures or time constraints, which are ubiquitous facts of existence in the modern corporate world, increased SC likely accentuates information processing errors characteristic of groupthink, such as selective processing bias, omissions in surveying alternatives and objectives, poor information search, a failure to examine the costs and risks of preferred choices, and a failure to reconsider originally rejected alternatives (cf. Esser 1998).

Analyses of network structures support the above reasoning. As observed earlier, centrally located network members, by virtue of closer proximity and greater power, are able to influence unduly the perceptions of wider network members, which in extremis can lead to unanimity of the sort characteristic of groupthink (cf. Ibarra and Andrews 1993; Walker 1985). Network ties are facilitated by similarity and homophily (Milton and Westphal 2005), which again can generate perceptual homogeneity, thereby fueling groupthink.

Once again, the errors mentioned above can occur both at the intra-organizational and interorganizational levels. At the intra-organizational level, for example, researchers have argued that groupthink played a role in the Challenger disaster (Moorhead et al. 1991) and, more recently, in the WorldCom accounting fraud (Scharff 2005). At the interorganizational level, groupthink has been found to undermine corporate communication initiatives (Ko 2005). Strategic groups theorists and researchers have also highlighted erroneous cognitive processes and outcomes akin to groupthink. Peteraf and Shanley (1997) have argued that strong identification within strategic groups often leads to interorganizational competitor blind spots, whereby potential or real competitors are not recognized or acknowledged. Empirical support for this proposition has been recorded (Porac et al. 1989; Reger and Huff 1993). Such blind spots have also been documented at the industry level (Abrahamson and Fombrun 1994; Hodgkinson 2005; Zajac and Bazerman 1991).

Although more recent research has cast doubt on some of the earlier arguments by Janis (1972) that groupthink played a role in Bay of Pigs invasion and military escalation of the Vietnam War (Kramer 1998), it is clear that the overwhelming weight of evidence surveyed above suggests that there are many organizational contexts in which groupthink does operate to undermine social information processing and decision making. In these circumstances, greater levels of SC arising from membership of dense networks likely exacerbate these effects, both within and across organizations, leading to poor decisions.

\section{Postponement of structural adjustments}

Managers often use organizational restructuring as a tool for addressing their business problems. Organizational structures aligned to the demands of operations and markets enable companies to achieve cost efficiencies and service improvements. Hence, restructuring can be an effective way to address the challenges posed by political, economic, social, technological, legal, and environmental changes. For example, many cement and paper manufacturers have redesigned their structures away from functionally based organizations to regional profit centers, in an attempt to optimize the trade-off needed to sell lowvalue commodities with high transportation costs. Semiconductor companies, in contrast, have evolved into product-based organizations, thus enabling them to serve multiple geographic regions without having a local presence, by distributing their products through third-party suppliers (Galbraith 2002; Oxman and Smith 2003). Restructuring can also be necessitated by organizational change and particular stages of the organizational life cycle are associated with particular structural characteristics and management systems (Churchill and Lewis 1983; Miller and Friesen 1984; Olson and Terpstra 1992).

Although restructuring may be necessary, organizational responses are typically tempered by the dominant logics prevailing (Prahalad and Bettis 1986) and the operating rules and programs that govern organizational activities (Cyert and March 1963). 
There is a dialectical tension between the forces of inertia and stability, on the one hand, and the forces of change, on the other, the resolution of which determines the extent and nature of change accomplished (Gordon et al. 2000). Forces for persistence include extant strategic commitments and power distributions (Pfeffer 1981), external stakeholder expectations (Hannan and Freeman 1984), and a host of psychological factors influencing managerial interpretations (Milliken and Lant 1991). Our argument is that SC, too, acts as an inertial force, impeding structural adjustments. The process by which SC hinders change is as follows.

Major structural transformations often provoke anxiety for the organization's employees and are difficult to manage (Olson and Terpstra 1992), because they threaten the extant social identities of managers and employees (Ashforth and Mael 1989; Scheepers and Ellemers 2005). Prior research has noted that high levels of anxiety inhibit the ability of individuals to visualize new directions and accept change that has NEGATIVE effects on salient identities (Scheepers and Ellemers 2005). Structural changes are often costly, because formal structures define membership of the formal groups with which members identify, in turn reinforcing the social sense of self. Hence, structural changes potentially undermine the ability of individuals to manage their identity concerns, triggering strong ego defense mechanisms deep in the limbic structures of the brain, which in turn breed active resistance (Hodgkinson and Healey 2011b, 2014). When contemplating structural adjustments, therefore, greater levels of SC, primarily cognitive and relational SC, will render managers more sensitive to the social identity concerns pertaining to their wider networks, in turn leading them to postpone such adjustments, thus detracting from organizational adaption (Abrahamson and Fombrun 1994; Hodgkinson and Healey 2011a, 2011b, 2014; Lant and Phelps 1999; Peteraf and Shanley 1997).

\section{Non-rational escalation of commitment}

Escalation of commitment refers to the tendency to adhere to a particular course of action even in the face of negative information concerning the viability of that course of action (Staw 1976, 1981). Among the prominent theories advanced to account for this phenomenon is self-justification theory (Staw 1976; Staw and Fox 1977), which posits that individuals escalate commitment in order to justify both to themselves and to significant others the rationality and 'correctness' of their past decisions. We maintain that SC exacerbates the incidence of such self-justification through (over-) identification with the relevant in-group. In so doing, we link the psychological and social determinants of the non-rational escalation of commitment (cf. Schmidt and Calantone 2002; Staw and Ross 1987; Wright and Goodwin 1999). Our argument is that the basic mechanism of social identification triggers 'social justification', a concept which extends the notion of self-justification to the social domain. Social justification denotes the process whereby members of the in-group feel the need to justify their collective decisions to a wider audience (the out-group), a process that is heightened when the decisions in question have the potential to result in deleterious outcomes.

We illustrate the above argument in the context of new product introduction, where the prevalence of escalation has been recorded (Schmidt and Calantone 2002). While deciding whether to continue support for a new product or venture, if the manager leading the project reversed an earlier 'go-decision', that earlier decision might well be viewed as a 'poor' decision within the company, reflecting badly not only on the manager in question, but also on the entire group of employees who had invested psychologically in the project, and who thus identified themselves with the project team. Hence, such a decision reversal would undermine the standing of the entire team within the wider organization (cf. Boulding et al. 1997). This is an important reason why some scholars (e.g. Staw 1981) have argued that the introduction of new decision makers at the time of stop/no stop decisions is the most effective method to reduce commitment to failing courses of action.

It has been noted that managers who initiate projects will be less likely to perceive them as failing and will thus be more likely to continue funding them than managers who assume leadership after the projects in question have commenced (Schmidt and Calantone 2002). Given the role of new decision makers in attenuating non-rational escalation, the presence of high levels of SC will hinder their effectiveness in two ways.

First, as demonstrated earlier, increased SC restricts the processing of new information pertinent to the problem at hand. In consequence, the decision making team as a whole will be more likely to hold highly similar views regarding the probability of the success of the new product, especially when the new leader is drawn from the center ground of the dense network encompassing the firm's managers. 
Second, high levels of SC, primarily relational SC, will put subtle pressure on the new leader to justify the decision of the previous leader, in order to avoid undermining the past incumbent's position. In this way, 'social justification' arising from high levels of SC constrains one of the most effective methods for containing escalation of commitment.

Previous research has documented the role of social factors such as public identification with the project in question and public norms of consistency in leading to escalation of commitment (Staw and Ross 1987). The deleterious effect of SC in this context merits further investigation. This additional mechanism might account better for the occurrence of escalation of commitment at the interorganizational level, as well as escalation within the organization.

\section{Blurring of firms' boundaries}

Coase (1937) pointed out that one of the key roles of boundaries is in determining resource allocation within firms. When resource allocation decisions are influenced by entities outside the firm, its boundaries get blurred, which in turn can have adverse consequences for decision making. Mullainathan (2001) has shown that vertically integrated firms are inwardly focused, holding capacity for internal demand and largely ignoring changes in external demand for their products. His study also finds potentially inefficient allocation of resources by such firms. Social capital at the interorganizational level, through its effects in integrating firms along the supply chain, has the potential to detract from the decision making efficiency of the buying firm, via a similar dynamic of inward focus and inefficient resource allocation.

Social identification theory provides support for this line of reasoning. The concept of 'attitude importance' captures the 'subjective sense of the concern, caring, and significance' an individual attaches to a particular attitude (Boninger et al. 1995, p. 62). At the interorganizational level it has been suggested that social identification can be thought of as a particularly potent driver of attitude importance (cf. Haslam et al. 2003). In a vertically integrated conglomerate, for example, when the members of partner firms identify with the wider network of organizations as a whole, they will attach attitude importance to preserving the SC that unites them and act accordingly. In such situations, decision makers will probably favor policies that are mutually beneficial to all of the organizational subunits concerned, seeking to optimize potentially conflicting priorities, rather than adopting choices that maximize the outcomes for some units at the expense of others. This assertion is supported by the finding in behavioral economics that cooperators place greater importance on fairness, whereas non-cooperators assign greater importance to self-interest when confronted with changes to the prevailing scenario (Samuelson 1993). Actors' attitudes toward fairness inform resource allocation decisions that are not necessarily in the best interests of the focal firm. Peteraf and Shanley's (1997) theory of strategic group identity also supports this line of reasoning. Peteraf and Shanley employed social identification theory to account for the emergence of the strong identities that characterize any group of rival firms sufficiently recognized and attended to by managers to affect individual member firms' actions. Factors that lead to such a strong sense of identity among collectives of firms include closeness of geographical proximity, the presence of dense social networks that transcend organizational boundaries, and cooperative norms, all of which are essential components of the three dimensions of SC identified by Nahapiet and Ghoshal (1998). Strong identity leads to collective action among the group of firms in question, thus influencing the resource allocation decisions of the focal firm within the strategic group. In addition to identification, norms of reciprocity, commitment, and obligations can also influence the resource allocation decisions of the focal firm.

Researchers have conjectured that the primary competition in the marketplace is not between pairs of firms, but between networks of firms or between supply chains (Moller and Halinen 1999). A key danger as these sorts of organizational collectives amass greater levels of SC is that their constituent member firms could potentially over-identify with one another, thus forming an in-group whose norms undermine innovation and change. Threatening events in the marketplace, such as changes in technology or aggressive moves by competitors, will be framed and perceived in terms that maintain an overall sense of strong group identity.

Price (1989) found that a news report emphasizing intergroup conflict led to polarized or exaggerated perceptions of in-group opinion, which in turn led to expressions of personal opinions consistent with those exaggerated perceived group norms. Extrapolating from this work, we conjecture that such collective framing of issues across firms results in collective decisions that are different from those that might otherwise result from more individualistic assessments 
of emerging scenarios. Here, too, we find SC in the form of social identification mediating the effects of external influences on the decision processes of the focal firm, such that SC leads to an unhealthy blurring of the focal firm's boundaries.

The foregoing analysis demonstrates that a further danger for organizations seeking to amass $\mathrm{SC}$ is the consequential danger of the blurring of their external boundaries, to the extent that the wider institutional networks in which they become embedded benefit the network at the expense of the focal firm (cf. Pfeffer and Salancik 1978). Such network arrangements can also lead to decision biases, not least because managers choose to align their firms' future activities with the past, in an attempt to preserve SC, believing that their conservative actions will be perceived as fairer by their counterparts in partner firms (Samuelson 1993).

\section{The role of moderators}

Several variables could moderate the relationships between SC and the deleterious intra- and interorganizational outcomes discussed above. In this section, we identify what we consider to be the most salient ones and offer future directions for the advancement of theory and research.

\section{Participative leadership}

At the intra-organizational level, participative leadership aids the dialectical process, by promoting dialogue and debate within the organization, thereby fostering individual and collective learning. Participative leadership — defined by Somech (2006, p. 135) as 'joint decision making, or at least shared influence in decision making, by a superior and his or her employees' (see also Koopman and Wierdsma 1998) has been shown to moderate the relationship between team heterogeneity and team reflection, such that the relationship is stronger in teams characterized by participative leadership (Somech 2006). Team reflection entails behaviors such as debating, questioning, planning, exploratory learning, divertive exploration and analyzing (West 1996). The cognitive processes associated with team reflection encourage team members to challenge each other on task-related issues, contributing in turn to constructive interactive practices (Simons et al. 1999; Somech 2006; Tjosvold 1990). The process of challenging and questioning team members is an essential element of team reflection, vital to the generation of antitheses, which in turn are re- quired to formulate syntheses. Hence, team reflection is central to the dialectical process discussed earlier.

Since participative leadership promotes team reflection, it follows that participative leadership positively influences both the dialectical process and individual and collective learning within organizations. It also follows that SC's negative effects on learning are likely to be stronger under lower levels of participative leadership; specifically, the theorized effects of SC on dilution of the dialectical process and inhibition of individual learning are likely to manifest themselves more strongly under such conditions. Under higher levels of participative leadership, in contrast, team reflection is encouraged and the dialectical process required to promote individual and collective learning will probably occur irrespective of SC. ${ }^{2}$

\section{Relative capabilities of the focal firm}

A second moderator that needs to be considered is the capabilities of the focal firm vis-à-vis its partners. Barney (1999) has noted how firms' capabilities affect boundary decisions. Arguing from a resourced-based perspective, he points out that creating and acquiring capabilities is a costly process; opportunism and governance costs, the foundational concepts of transactions cost theory (Coase 1937), are not the only considerations that the firm should keep in mind. Factors such as historical context, social complexity, and path dependence need to be considered while creating capabilities in house, whereas strategic flexibility, the extent of diffusion of the capabilities of the target firm, and legal constraints need to be taken into account when seeking to acquire capabilities through mergers and acquisitions, strategic alliances, and joint ventures. We infer that the boundary decisions of firms are determined, in part, by the

\footnotetext{
${ }^{2}$ From a dual-systems perspective (e.g. Lieberman 2007), as argued by Healey et al. (2015), team reflection is necessary not only as a basis for challenging actors' explicit (reflective) mental models pertaining to the functioning of the organizational collectives to which they belong (e.g. their mental models of fellow team members' capabilities, the task environment, and the goals at hand), but also for challenging their implicit (reflexive) mental representations (especially implicit attitudes, subconscious goals, and implicit stereotypes) that can variously moderate the impact of those explicit representations, especially under conditions of acute time pressure and cognitive load. Consistent with the above line of reasoning, however, such negative effects are less likely under higher levels of participative leadership, which, by definition, will enhance team interaction and aid deliberation.
} 
capabilities of the focal firm relative to its potential partners. When it is feasible to acquire capabilities by means of partnerships, the boundaries of the firm are extended, whereas when capability development is not feasible by these means, its boundaries are drawn tighter. The latter situation will force the firm to develop its capabilities by recourse to the market. The capabilities of potential partners also affect the boundary decisions of the focal firm, in as much as the costs of forming such partnerships get built into the decision as to whether the focal firm should create the new capabilities desired in house or acquire them externally.

Since the focal firm's capabilities influence its boundary decisions, they also moderate the effect of SC on the blurring of its boundaries. The strategy literature has noted that organizational networks are often characterized by power asymmetries (Subramani and Venkatraman 2003) and asymmetry in terms of capabilities will contribute to such power asymmetries. When the focal firm has higher levels of capabilities relative to its partners, it enjoys greater power; accordingly, it is less likely to be influenced by those partners. Conversely, however, when the focal firm has lower capabilities relative to its partners, it is more susceptible to the latter's influence, irrespective of the level of SC. Hence, the effect of SC on the blurring of firms' boundaries is likely to be stronger when the focal firm enjoys greater relative power.

\section{Transaction-specific investments}

Transaction-specific investments (TSIs) are assets that have very little value outside a particular relationship (Williamson 1985). We maintain that the presence of TSIs moderates two of the negative effects of SC that we have identified at the interorganizational level.

First, irrespective of whether they are physical assets or human assets, TSIs are generally dedicated to a particular supplier. Hence, their redeployment entails considerable switching costs (Erramilli and Rao 1993; Heide 1994), rendering more likely the postponement of major structural adjustments. In other words, the effect of SC on the postponement of structural adjustments will be more pronounced in the absence of TSIs.

Second, TSIs increase buyers' dependence on the focal supplier (Ganesan 1994; John and Weitz 1989). It thus follows that higher levels of TSI could lower the negative effect of SC on the blurring of firms' boundaries, because TSIs create buyer dependence on the supplier, thus affording influence to the latter in respect of the former's decisions, irrespective of the level of SC. However, in the absence of TSIs, the foregoing theorized role of SC in blurring the firm's boundaries is likely to manifest more strongly.

\section{Environmental turbulence}

Strategic choice theorists have suggested that constraining factors, including the external environment, play an important role in shaping strategic choice (Child 1972). Organizational fit theories, too, have underscored the necessity of coping with environmental change (McKee et al. 1989; Miles and Snow 1978).

Following this line of reasoning, we maintain that environmental turbulence has a moderating effect on the links between SC and structural adjustment. Environmental turbulence is defined as '(1) high levels of inter-period change (in magnitude and/or direction) in the levels or values of key environmental variables, and (2) considerable uncertainty and unpredictability as to the future values of these variables' (Glazer and Weiss 1993, p. 510). Firms operating in highly turbulent environments will be more willing to impose the pain of structural adjustments on employees and partners relative to those operating in more stable environments because, when environmental change is pervasive, frame-breaking or difficult to predict, the organization must be capable of rapid change to survive (D'Aveni 1994). In these circumstances, piecemeal, incremental adaptation is inadequate. This argument is based on the notion that strategic decision makers mediate organization-environment interactions (Darren and Snow 1975). Empirical support for the assertion that environmental turbulence will lead to structural change is provided by Gordon et al. (2000), who found that turbulence is a precursor to strategic reorientation, operationalized in terms of changes in the organization to at least two of the following: organizational structure; the distribution of power; and the organization's control systems. It can be seen that all three aspects of strategic reorientation identified by Gordon et al. (2000) fall within the purview of structural adjustment, as discussed earlier. As we have seen, with increased SC, managers tend to postpone structural adjustments both at the interorganizational and the intra-organizational levels. When turbulence is high, managers are more likely to initiate structural changes because there is greater pressure to survive, irrespective of SC. When environmental turbulence is low, however, the process 
whereby SC inhibits structural adjustments, theorized earlier, is more likely to assert itself.

\section{Concluding remarks}

In marked contrast to the prevailing emphasis in the management literature on the putative benefits of increased SC for individuals and organizations, this paper has identified several negative effects, both at the intra- and interorganizational levels of analysis, with a focus on the socio-cognitive mechanisms underpinning those effects. It has also proposed potential moderators of the deleterious effects thus identified. In so doing, it has contributed new theory to the emerging discourse on the dark side of SC in organizational contexts. Accordingly, it will hopefully help to ensure that future work examining the nature and consequences of SC in organizational contexts adopts a more balanced perspective.

Through a review of various well-established concepts in social psychology, organization theory and related literatures, we have advanced a series of generative mechanisms centered on social identification processes, interconnecting individual organizational actors with the social structures in which they and their wider organizations are embedded (cf. Ibarra et al. 2005; Kilduff and Krackhardt 1994). We have proposed that high levels of SC can result in: (1) dilution of the dialectical process; (2) the inhibition of individual (and collective) learning within organizations; (3) groupthink; (4) the postponement of structural adjustments; (5) the non-rational escalation of commitment to failing courses of action; and (6) the blurring of firms' boundaries. We have argued that these negative effects arise primarily from dysfunctional social identification processes that restrict the processing of pertinent new information. Finally, we have identified potential moderating effects of participative leadership, the relative capabilities of the focal firm, TSIs, and environmental turbulence on the proposed deleterious consequences of increased SC.

Although in the course of developing our arguments we have alluded to which particular forms of SC (structural, relational and cognitive) we consider most prominent in relation to specific lines of reasoning, we have refrained from a strict compartmentalization of the SC construct into its constituent dimensions, because, as argued at the outset, we see social identification, the primary mechanism through which the processes enumerated in the foregoing sections operate, as foundational to all three forms of SC (cf. Ibarra et al. 2005; Kilduff and Cor- ley 1999; Kilduff and Tsai 2003; Tsai and Ghoshal 1998).

Our analysis implies a linear progression of social identification processes leading to dilution of the dialectical process and inhibition of individual learning, in turn leading to groupthink and further resulting in the postponement of structural adjustments, nonrational escalation of commitment and the blurring of organizational boundaries. We remain open, however, to the possibility of reciprocal causation, both among the various deleterious consequences of excessive SC accumulation we have identified, and in terms of the links between identification processes and the outcomes in question. Mindful that identities are multiply determined (e.g. geographic, demographic, and relational factors can cause strong identities to emerge), our intention in this paper was merely to take the first steps toward the development of a more focused and integrative account of the more obvious negative effects resulting from the potentially dysfunctional (over-) identification processes that likely arise whenever there is an excess accumulation of SC in work-related contexts.

A major priority for future research is to test empirically each of the main and moderating effects advanced in this paper. Future research could also usefully theorize and test empirically additional potential moderators. Such an exercise would advance management and organization theory by enabling the development of more nuanced and fine-grained accounts of SC and its diverse effects within and between organizations. It would also contribute to practice by helping managers to become attuned to the negative effects of excessive SC accumulation under varying conditions, allowing them to take appropriate measures, as and when necessary, to mitigate the risks thus identified.

Going forward, SC theorists will need to integrate the well-documented positive effects of SC in organizational contexts with the negative ones identified in the present paper. The presence of positive and negative effects leads us to believe that there is an optimal level of SC in a given situation. Following the empirical findings reviewed earlier, we maintain that, up to a certain point, the initial gains derived from SC will outweigh the losses. However, at higher levels, the negative effects theorized in this paper will assert themselves. Accordingly, the positive effects emphasized in the extant literature and the negative ones previously under-theorized, can be conceptualized as a series of functional relationships, each of which takes the form of an inverted-U shape. 
Of immediate interest are the relative magnitudes and position of the inflection points associated with each of these functions (for example, the curve depicting the relationship between SC and the inhibition of individual level learning and the one depicting the impact of SC on the postponement of structural adjustments). New empirical research is required in order to inform this line of thinking further before more specific inferences can be drawn. Another potentially fruitful direction for future research is to examine how the balance or imbalance of positive and negative ties in networks might drive the particular identity dynamics that shape variously the balance of positive and dark side outcomes of SC.

In conclusion, this paper has contributed much needed new theory to the literature on SC by first identifying several hitherto neglected potential negative effects of SC and then elucidating the sociocognitive mechanisms underpinning those effects. Such a focus is appropriate at this juncture, as the bulk of the extant literature on SC has focused on its structural and relational aspects. We hope that by offering a more balanced, integrative view, the present contribution will stimulate the new wave of empirical work now required to advance research and practice even further.

\section{References}

Abrahamson, E. and Fombrun, C.J. (1994). Macrocultures: determinants and consequences. Academy of Management Review, 19, pp. 728-755.

Acquaah, M. (2007). Managerial social capital, strategic orientation, and organizational performance in an emerging economy. Strategic Management Journal, 28, pp. 12351255

Acquaah, M. and Appiah-Nkrumah, J. (2011). Firm-specific managerial experience and the social capital-performance relationship in a sub-Saharan African transition economy. Journal of African Business, 12, pp. 8-30.

Adler, P.S. and Kwon, S.-W. (2002). Social capital: prospects for a new concept. Academy of Management Review, 27, pp. $17-40$.

Ahearne, M., Lam, S.K. and Kraus, F. (2014). Performance impact of middle managers' adaptive strategy implementation: the role of social capital. Strategic Management Journal, 35, pp. 68-87.

Andrist, L.H. (2008). Social capital's dark side and patriarchy in India. MA thesis, University of Maryland, College Park, MD.

Argyris, C. (1994). Good communication that blocks learning. Harvard Business Review, 72, pp. 77-85.
Arneil, B. (2006). Diverse Communities: The Problem With Social Capital. New York, NY: Cambridge University Press.

Ashforth, B.E. and Mael, F. (1989). Social identity theory and the organization. Academy of Management Review, 14, pp. 20-39.

Bandura, A. (1986). Social Foundations of Thought and Action. Englewood Cliffs, NJ: Prentice-Hall.

Barney, J.B. (1999). How a firm's capabilities affect boundary decisions. Sloan Management Review, 40, pp. 137-145.

Batjargal, B. (2003). Social capital and entrepreneurial performance in Russia: a longitudinal study. Organization Studies, 24, pp. 535-556.

Batjargal, B. (2007). Internet entrepreneurship: social capital, human capital, and performance of Internet ventures in China. Research Policy, 36, pp. 605-618.

Belliveau, M.A., O'Reilly, C.A. and Wade, J.B. (1996). Social capital at the top: effects of social similarity and status on CEO compensation. Academy of Management Journal, 39, pp. 1568-1593.

Bridwell-Mitchell, E.N. and Lant, T.K. (2014). Be careful what you wish for: the effects of issue interpretation on social choices in professional networks. Organization Science, 25, pp. 401-419.

Boninger, D.S., Berent, M.K. and Krosnick, J.A. (1995). Origins of attitude importance: self-interest, social identity, and value relevance. Journal of Personality and Social Psychology, 68, pp. 61-80.

Boulding, W., Morgan, R. and Staelin, R. (1997). Pulling the plug to stop the new product drain. Journal of Marketing Research, 34, pp. 164-176.

Bourdieu, P. (1986). The forms of capital. In Richardson J.G. (ed.), Handbook of Theory and Research for the Sociology of Education. New York, NY: Greenwood Press, pp. 241258.

Burt, R.S. (1992). Structural Holes. The Social Structure of Competition. Cambridge, MA: Harvard University Press. Burt, R.S. (1997). The contingent value of social capital. Administrative Science Quarterly, 42, pp. 339-366.

Byrne, D. (1971). The Attraction Paradigm. New York, NY: Academic Press.

Chetty, S. and Agndal, H. (2007). Social capital and its influence on changes in internationalization mode among small and medium-sized enterprises. Journal of International Marketing, 15, pp. 1-29.

Churchill, N. and Lewis, V.L. (1983). The five stages of small business growth. Harvard Business Review, 61, pp. 3050.

Child, J. (1972). Organization structure, environment, and performance: the role of strategic choice. Sociology, $\mathbf{6}$, pp. 2-22.

Coase, R. (1937). The nature of the firm. Economica, 4, pp. 386-405.

Coleman, J.S. (1988). Social capital in the creation of human capital. American Journal of Sociology, 94 (Supplement), pp. S95-S120. 
Coleman, J.S. (1990). The Foundations of Social Theory. Cambridge, MA: Belknap.

Collins, J.D. (2006). Social capital's dark side: knowledge, reciprocity, and the liability of relationships. PhD dissertation, Texas A\&M University.

Cornelissen, J.P., Haslam, S.A. and Balmer, J.M. T. (2007). Social identity, organizational identity, and corporate identity: towards an integrated understanding of processes, patternings and products. British Journal of Management 18, pp. S1-S16.

Cyert, R.M. and March, J.G. (1963). A Behavioral Theory of the Firm. Englewood Cliffs, NJ: Prentice-Hall.

Daft, R.L. and Weick, K.E. (1984). Toward a model of organizations as interpretation systems. Academy of Management Review, 9, pp. 284-295.

Darren, D. and Snow, C. (1975). Organizational adjustment to the environment: a review. American Institute for Decision Sciences Proceedings, pp. 278-281.

D'Aveni, R.A. (1994). Hyper-competition. New York, NY: Free Press.

de Clercq, D., Thongpapanl, N. and Dimov, D. (2009). When good conflict gets better and bad conflict becomes worse: the role of social capital in the conflict-innovation relationship. Journal of the Academy of Marketing Science, 37, pp. 283-297.

DeFillippi, R. and Ornstein S. (2003). Psychological perspectives underlying theories of organizational learning. In Easterby-Smith, M. and Lyles, M.A. (eds), The Blackwell Handbook of Organizational Learning and Knowledge Management. Oxford: Blackwell.

Durkheim, É. [1895](1938). The Rules of Sociological Method, trans. S.A. Solovay and J.H. Mueller. Glencoe, IL: Free Press.

Durkheim, É. [1902-03] (1961). Moral Education, trans. E.K. Wilson and H. Schnurer. New York, NY: Free Press.

Edelman, L.F., Bresnen, M., Newell, S., Scarbrough, H. and Swan, J. (2004). The benefits and pitfalls of social capital: empirical evidence from two organizations in the United Kingdom. British Journal of Management, 15(S1), pp. S59-S69.

Eklinder-Frick, J.; Eriksson, L.T. and Hallen, L. (2011). Bridging and bonding forms of social capital in a regional strategic network. Industrial Marketing Management, 40, pp. 994-1003.

Eklinder-Frick, J., Eriksson, L.T. and Hallen, L. (2012). Effects of social capital on processes in a regional strategic network. Industrial Marketing Management, 41, pp. 800806.

Elkjaer, B. (2003). Social learning theory: learning as participation in social processes. In Easterby-Smith, M. and Lyles, M.A. (eds), The Blackwell Handbook of Organizational Learning and Knowledge Management. Oxford: Blackwell.

Elkjaer, B. (2005). From digital administration to organizational learning. Journal of Workplace Learning, 17, pp. 533-544.
Elkjaer, B. and Huysman, M. (2008). Social worlds theory and the power of tension. In Barry, D. and Hansen, H. (eds), The Sage Handbook of New Approaches in Management and Organization. London: Sage, pp. 170-177.

Erramilli, M.K. and Rao, C.P. (1993). Service firms' international entry-mode choice. Journal of Marketing, 57(July), pp. 19-38.

Esser, J.K. (1998). Alive and well after 25 years: a review of groupthink research. Organizational Behavior and Human Decision Processes, 73, pp. 116-141.

Fazio, G. and Lavecchia, L. (2013). Social capital formation across space: proximity and trust in European regions. International Regional Science Review, 36, pp. 296-321.

Florida, R., Cushing, R. and Gates, G. (2002). When social capital stifles innovation. Harvard Business Review, 80, p. 20.

Foley, M.W. and Edwards, B. (1999). Is it time to disinvest in social capital? Journal of Public Policy, 19, pp. 141173.

Gabbay, S.M. and Leenders, R.Th.A.J. (1999). CSC: the structure of advantage and disadvantage. In Leenders, R.Th.A.J. and Gabbay, S.M. (eds), Corporate Social Capital and Liability. Boston, MA: Kluwer Academic, pp. 114.

Ganapati, N.E. (2013). Downsides of social capital for women during disaster recovery: toward a more critical approach. Administration and Society, 45, pp. 72-96.

Galbraith, J.R. (2002). Designing Organizations: An Executive Guide to Strategy, Structure, and Process. San Francisco, CA: Jossey Bass.

Ganesan, S. (1994). Determinants of long-term orientation in buyer-seller relationships. Journal of Marketing, 58(April), pp. 1-19.

Gargiulo, M. and Benassi, M. (1999). The dark side of social capital. In Leenders, R.T. A.J. and Gabbay, S.M. (eds), Corporate Social Capital and Liability. Boston, MA: Kluwer.

Gargiulo, M. and Benassi, M. (2000). Trapped in your own net? Network cohesion, structural holes and the adaptation of social capital. Organization Science, 11, pp. 183196.

Gioia, D.A. (1986). Conclusion: the state of the art in organizational social cognition: a personal view. In Sims, H. and Gioia, D. (eds), The Thinking Organization: Dynamics of Organizational Social Cognition. San Francisco, CA: Jossey-Bass, pp. 336-356.

Glazer, R. and Weiss, A.M. (1993). Marketing in turbulent environments: decision processes and the timesensitivity of information. Journal of Marketing Research, 30, pp. 509-521.

Godesiabois, J. (2008). It's not all good: the negative influence of social capital on new firm performance. Frontiers of Entrepreneurship Research, 28(3), Article 6.

Gordon, S.S., Stewart, W.H. Jr, Sweo, R. and Luker, W.A. (2000). Convergence versus strategic reorientation: the antecedents of fast-paced organizational change. Journal of Management, 26, pp.911-945. 
Grabher, G. (1993). The weakness of strong ties: the lock-in of regional development in the Ruhr area. In Grabher, G. (ed.), The Embedded Firm. London: Routledge, pp. 255277.

Grootaert, C. (2001). Does social capital help the poor? A synthesis of findings from the Local Level Institutions studies in Bolivia, Burkina Faso and Indonesia. Local Level Institutions Working Paper Series No. 10. Environment and Socially Sustainable Development (ESSD) Division, World Bank, Washington DC.

Grugulis, I. and Stoyanova, D. (2012). Social capital and networks in film and TV: jobs for the boys? Organization Studies, 33, pp. 1311-1331.

Gu, F.F., Hung, K. and Tse, D.K. (2008). When does guanxi matter? Issues of capitalization and its dark sides. Journal of Marketing, 72, pp. 12-28.

Hannan, M.T. and Freeman, J.H. (1984). Structural inertia and organizational change. American Sociological Review, 49, pp. 149-164.

Haslam, S.A., Eggins, R.A. and Reynolds, K.J. (2003). The ASPIRe model: actualizing social and personal identity resources to enhance organizational outcomes. Journal of Occupational and Organizational Psychology, 76, pp. 83113.

Healey, M.P., Vuori, T. and Hodgkinson, G.P. (2015). When teams agree while disagreeing: reflexion and reflection in shared cognition. Academy of Management Review, 40, pp. 399-422.

Heide, J.B. (1994). Interorganizational governance in marketing channels. Journal of Marketing, 58(January), pp. 7185 .

Hodgkinson, G.P. (2003). Review of 'The Blackwell Handbook of Organizational Learning and Knowledge Management' by Mark Easterby-Smith and Marjorie A. Lyles. Administrative Science Quarterly 48, pp. 699-703.

Hodgkinson, G.P. (2005). Images of Competitive Space: A Study of Managerial and Organizational Strategic Cognition. Basingstoke: Palgrave Macmillan.

Hodgkinson, G.P. and Healey, M.P. (2011a). Interorganizational macrocultures: a multilevel critique. In Ashkanasy, N.M., Wilderom, C.P.M. and Peterson, M.F. (eds), The Handbook of Organizational Culture and Climate, 2nd edn. London: Sage, pp. 291-316.

Hodgkinson, G.P. and Healey, M.P. (2011b). Psychological foundations of dynamic capabilities: reflexion and reflection in strategic management. Strategic Management Journal, 32, pp. 1500-1516.

Hodgkinson, G.P. and Healey, M.P. (2014). Coming in from the cold: the psychological micro-foundations of radical innovation revisited. Industrial Marketing Management, 43, pp. 1306-1313.

Hodgkinson, G.P. and Sparrow, P.R. (2002). The Competent Organization: A Psychological Analysis of the Strategic Management Process. Buckingham: Open University Press.
Huggins, R. (2010). Forms of network resource: knowledge access and the role of inter-firm networks. International Journal of Management Reviews, 12, pp. 335-352.

Ibarra, H. and Andrews, S. (1993). Power, social influence and sense making: effects of network centrality and proximity on employee perceptions. Administrative Science Quarterly, 38, pp. 277-303.

Ibarra, H., Kilduff, M. and Tsai, W. (2005). Zooming in and out: connecting individuals and collectivities at the frontiers of organizational network research. Organization Science, 16, pp. 359-371.

Inkpen, A.C. and Tsang, E.W.K. (2005). Social capital, networks, and knowledge transfer. Academy of Management Review, 30, pp. 146-165.

Janis, I.L. (1972). Victims of Groupthink. Boston, MA: Houghton Mifflin.

Janis, I.L. (1982). Groupthink. Boston, MA: Houghton Mifflin.

Jansen, R.J.G., Curseu, P.L., Vermeulen, P.A.M., Geurts, J.L.A. and Gibcus, P. (2011). Social capital as a decision aid in strategic decision making in service organizations. Management Decision, 49, pp. 734-747.

Jansen, R.J.G., Curseu, P.L., Vermeulen, P.A.M., Geurts, J.L.A. and Gibcus, P. (2013). Information processing and strategic decision making in small and medium-sized enterprises: the role of human and social capital in attaining decision effectiveness. International Small Business Journal, 31, pp. 192-216.

Jensen, D.H. and Jetten, J. (2015). Bridging and bonding interactions in higher education: social capital and students' academic and professional identity formation. Frontiers in Psychology, 6, Article 126, doi: 10.3389/fpsyg.2015.00126.

John, G. and Weitz, B. (1989). Sales force compensation: an empirical investigation of factors related to use of salary versus incentive compensation. Journal of Marketing Research, 26(February), pp. 1-14.

Jonas, E., Schulz-Hardt, S., Frey, D. and Thelen, N. (2001). Confirmation bias in sequential information search after preliminary decisions: an expansion of dissonance theoretical research on selective exposure to information. Journal of Personality and Social Psychology, 80, pp. 557571.

Jordan, J.L. and Munasib, A.B.A. (2006). Motives and social capital consequence. Journal of Economic Issues, 40, pp. 1093-1112.

Kilduff, M. and Corley, K.G. (1999). The diaspora effect: the influence of exiles on their cultures of origin. Management, 2, pp. 1-12.

Kilduff, M. and Krackhardt, D. (1994). Bringing the individual back in: a structural analysis of the internal market for reputation in organisations. Academy of Management Journal, 37, pp. 87-108.

Kilduff, M. and Tsai, W. (2003). Social Networks and Organizations. London: Sage. 
Ko, A.S.O. (2005). Organizational communication in Hong Kong: a cultural approach to groupthink. Corporate Communications, 10, pp. 351-357.

Koopman, P.L. and Wierdsma, A.F.M. (1998). Participative management. In Doentu, P.J. D., Thierry, H. and deWolf, C.J. (eds), Personnel Psychology: Handbook of Work and Organizational Psychology. Hove: Psychology Press, pp. 297-324.

Kostova, T. and Roth, K. (2003). Social capital in multinational corporations and a micro-macro model of its formation. Academy of Management Review, 28, pp. 297-317.

Kramer, R.M. (1998). Revisiting the bay of pigs and Vietnam decisions 25 years later: how well has the groupthink hypotheses stood the test of time? Organizational Behavior and Human Decision Processes, 73, pp. 236-271.

Krishna, A. and Shrader, E. (2000). Cross-sectoral measures of social capital: a tool and results from India and Panama.

Social Capital Initiative Working Paper No. 21. Social Development Department, World Bank, Washington, DC. Kwon, S.-W. and Adler, P.S. (2014). Social capital: maturation of a field of research. Academy of Management Review, 39, pp. 412-422.

Lant, T.K. and Phelps, C. (1999). Strategic groups: a situated learning perspective. Advances in Strategic Management, 16, pp. 221-247

Laursen, K., Masciarelli, F. and Prencipe, A. (2012). Trapped or spurred by the home region: the effects of potential social capital on involvement in foreign markets for goods and technology. Journal of International Business Studies, 43, pp. 783-807.

Lave, J. and Wenger, E. (1991). Situated Learning: Legitimate Peripheral Participation. Cambridge: Cambridge University Press.

Lee, R. (2009). Social capital and business and management: setting a research agenda. International Journal of Management Reviews, 11, pp. 247-273.

Lee, R. and Tuselmann, H. (2013). Entrepreneurship, occupational division and social capital differentials. Journal of Small Business and Enterprise Development, 20, pp. 661680.

Li, Y., Wang, X, Huang, L. and Bai, X. (2013). How does entrepreneurs' social capital hinder new business development? A relational embeddedness perspective. Journal of Business Research, 66, pp. 2418-2424.

Lieberman, M.D. (2007). Social cognitive neuroscience: a review of core processes. Annual Review of Psychology, 58, pp. 259-289.

Lindstrand, A., Melen, S. and Nordman, E.R. (2011). Turning social capital into business: a study of the internationalization of biotech SMEs. International Business Review, 20, pp. 194-212.

Locke, E.A. (1999). Some reservations about social capital, Academy of Management Review, 24, pp. 8-9.

Luk, C.-L., Yau, O.H.M., Sin, L.Y.M., Tse, A.C.B., Chow, R.P.M. and Lee, J.S.Y. (2008). The effects of social capital and organizational innovativeness in different institutional contexts. Journal of International Business Studies, 39, pp. 589-612.

Lutter, M. (2015). Do women suffer from network closure: the moderating effect of social capital on gender inequality in a project-based labor market, 1929 to 2010. American Sociological Review, 80, pp. 329-358.

Mackie, D.M. (1986). Social identification effects in group polarization. Journal of Personality and Social Psychology, 50, pp. 720-728.

Maghrabi, R.O., Oakley, R.L. and Nemati, H.R. (2013). The impact of self-selected identity on productive or perverse social capital in social network sites. Computers in Human Behavior, 33, pp. 367-371.

Malecki, E.J. (2012). Regional social capital: why it matters. Regional Studies, 46, pp. 1023-1039.

Malik, T. (2012). Disparate association between alliance social capital and the global pharmaceutical firm's performance. International Business Review, 21, pp. 10171028.

Martin, J.L. (2002). Power, authority, and the constraint of belief systems. American Journal of Sociology, 107, pp. 861904.

Martinez, M.A. and Aldrich, H.E. (2011). Networking strategies for entrepreneurs: balancing cohesion and diversity. International Journal of Entrepreneurial Behaviour \& Research, 17, pp. 7-38.

Maurer, I. and Ebers, M. (2006). Dynamics of social capital and their performance implications: lessons from biotechnology start-ups. Administrative Science Quarterly, 51, pp. 262-292.

Maurer, I., Bartsch, V. and Ebers, M. (2011). The value of intra-organizational social capital: how it fosters knowledge transfer, innovation performance, and growth. Organization Studies 32, pp. 157-185.

McKee, D.O., Varadarajan, P.R. and Pride, W.M. (1989). Strategic adaptability and firm performance: a market contingent perspective. Journal of Marketing, 53, pp. 21-35.

McLean, S. (2007/8). Review of 'Diverse Communi- ties: the Problem with Social Capital' by Barbara Arneil.' Political Science Quarterly, 122, pp. 683685.

Miles, R.E. and Snow, C.C. (1978). Organizational Strategy, Structure, and Process. New York, NY: McGraw Hill.

Miller, D. and Friesen, P.H. (1984). A longitudinal study of the corporate life cycle. Management Science, 30, pp. 1161-1183.

Milliken, F.J. and Lant, T.K. (1991). The effect of an organization's recent performance history on strategic persistence and change: the role of managerial interpretations. In Dutton, J., Huff, A. and Shrivastava, P. (eds), Advances in Strategic Management. Greenwich, CT: JAI Press, Vol. 7, pp. 125-152.

Milton, L.P. and Westphal, J.D. (2005). Identity confirmation networks and cooperation in workgroups. Academy of Management Journal, 48, pp. 191-212.

Molina-Morales, F.X. and Martinez-Fernandez, M.T. (2010). Social networks: effects of social capital on firm 
innovation. Journal of Small Business Management 48 , pp. 258-279.

Moller, K.K. and Halinen, A. (1999). Business relationships and networks: managerial challenge of network era. Industrial Marketing Management, 28, pp.413-427.

Moorhead, G., Ference, R.J. and Neck, C.P. (1991). Group decision fiascoes continue: Space shuttle Challenger and a revised groupthink framework. Human Relations, 44, pp. 539-550.

Moran, P.(2005). Structural vs. relational embeddedness: social capital and managerial performance. Strategic Management Journal, 26, pp. 1129-1151.

Mullainathan, S. (2001). Do firm boundaries matter? American Economic Review, 91, pp. 195-199.

Nahapiet, J. and Ghoshal, S. (1998). Social capital, intellectual capital and the organizational advantage. Academy of Management Review, 23, pp. 242-266.

Nicolini, D. and Meznar, M.B. (1995). The social construction of organizational learning: Conceptual and practical issues in the field. Human Relations, 48, pp. 727746.

Nonaka, I. and Takeuchi, H. (1995). The KnowledgeCreating Company. New York, NY: Oxford University Press.

Nonaka, I. and Toyama, R. (2002). A firm as a dialectical being: towards a dynamic theory of a firm. Industrial and Corporate Change, 11, pp. 995-1009.

Oh, H., Chung, M. and Labianca, G. (2004). Group social capital and group effectiveness: the role of informal socializing ties. Academy of Management Journal, 47, pp. 860875.

Olson, P.D. and Terpstra, D.E. (1992). Organizational structural changes: life cycle stage influences and managers' and interventionists' challenges. Journal of Organizational Change Management, 5, pp. 27-40.

Oxman, J.A. and Smith, B.D. (2003). The limits of structural change. MIT Sloan Management Review, 45, pp. 7782.

Peteraf, M. and Shanley, M. (1997). Getting to know you: a theory of strategic group identity. Strategic Management Journal, 18(Summer Special Issue), pp. 165-186.

Pfeffer, J. (1981). Power in Organizations. Cambridge, MA: Ballinger.

Pfeffer, J. and Salancik, G.R. (1978). The External Control of Organizations: A Resource Dependence Perspective. New York, NY: Harper \& Row.

Pittaway, L., Robertson, M., Munir, K. Denyer, D., Neely, A. (2004). Networking and innovation: a systematic review of the evidence. International Journal of Management Reviews, 5/6, pp. 137-168.

Pollock, T.G. (2004). The benefits and costs of underwriters' social capital in the U.S. initial public offerings market. Strategic Organization, 2, pp. 357-388.

Porac, J.F., Thomas, H. and Baden-Fuller, C. (1989). Competitive groups as cognitive communities: the case of Scottish knitwear manufacturers. Journal of Management Studies, 26, pp. 397-416.

Portes, A. (1998). Social capital: its origin and applications in modern sociology. Annual Review of Sociology, 24, pp. 1-24.

Portes, A. and Vickstrom, E. (2011). Diversity, social capital, and cohesion. Annual Review of Sociology, 37, pp. 461479.

Powell, W.W. and Smith-Doerr, L. (1994). Networks and economic life. In Smelser, N.J. and Swedberg, R.R. (eds), The Handbook of Economic Sociology. Princeton, NJ: Princeton University Press, pp. 368-402.

Prahalad, C.K. and Bettis, R.A. (1986). The dominant logic: a new linkage between diversity and performance. Strategic Management Journal, 7, pp.485-501.

Presutti, M., Boari, C. and Fratocchi, L. (2007). Knowledge acquisition and the foreign development of high-tech startups: a social capital approach. International Business Review, 16, pp. 23-46.

Price, V. (1989). Social identification and public opinion effects of communicating group conflict. Public Opinion Quarterly, 53, pp. 197-224.

Putnam, R.D. (2000). Bowling Alone: The Collapse and Revival of American Community. New York, NY: Simon \& Schuster.

Richter, I. (1998). Individual and organizational learning at the executive level: towards a national agenda. Management Learning, 29, pp. 299-316.

Reger, R.K. and Huff, A.S. (1993). Strategic groups: a cognitive perspective. Strategic Management Journal, 14, pp. 103-124.

Rost, K. (2011). The strength of strong ties in the creation of innovation. Research Policy 40, pp. 588-604.

Rouzies, D. and Hulland, J. (2014). Does marketing and sales integration always pay off? Evidence from a social capital perspective. Journal of the Academy of Marketing Science, 42, pp. 511-527.

Salancik, G.R. and Pfeffer, J. (1978). A social information processing approach to job attitudes and task design. $A d$ ministrative Science Quarterly, 23, pp. 224-252.

Samuelson, C.D. (1993). A multiattribute evaluation approach to structural change in resource dilemmas. Organizational Behavior and Human Decision Processes, 55, pp. 298-324.

Scharff, M.M. (2005). Understanding WorldCom's accounting fraud: did groupthink play a role? Journal of Leadership \& Organization Studies, 11, pp. 109-118.

Scheepers D. and Ellemers, N. (2005). When the pressure is up: the assessment of social identity threat in low and high status groups. Journal of Experimental Social Psychology, 41, pp. 192-200.

Schmidt, J.B. and Calantone, R.J. (2002). Escalation of commitment during new product development. Journal of the Academy of Marketing Science, 30, pp. 103118. 
Scott, S.G. (1997). Social identification effects in products and process development teams. Journal of Engineering and Technology Management, 14, 97-127.

Simons, T., Pelled, L.H. and Smith, K.A. (1999). Making use of difference: diversity, debate, and decision comprehensiveness in top management teams. Academy of Management Journal, 42, pp. 662-673.

Singh, P.V., Tan, Y. and Mookerjee, V. (2011). Network effects: the influence of structural capital on open source project success. MIS Quarterly, 35, pp. 813-829.

Somech, A. (2006). The effects of leadership style and team process on performance and innovation in functionally heterogeneous teams. Journal of Management, 32, pp. 132157.

Spender, J.-C. (1989). Industry Recipes: The Nature and Sources of Managerial Judgement. Oxford: Basil Blackwell.

Spender, J.-C. (1996). Making knowledge the basis of a dynamic theory of the firm. Strategic Management Journal, 17, pp. 45-62.

Staber, U. (2007). Contextualizing research on social capital in regional clusters. International Journal of Urban and Regional Research, 31, pp.505-521.

Stam, W. and Elfring, T. (2008). Entrepreneurial orientation and new venture performance: the moderating role of intraand extraindustry social capital. Academy of Management Journal, 51, pp. 97-111.

Staw, B.M. (1976). Knee-deep in the big muddy: a study of escalating commitment to a chosen course of action. Organizational Behavior and Human Performance, 16, pp. $27-44$.

Staw, B.M. (1981). The escalation of commitment to a course of action. Academy of Management Review, 6, pp. 577587.

Staw, B.M. and Fox, F.V. (1977). Escalation: the determinants of commitment to a chosen course of action. Human Relations, 30, pp. 431-450.

Staw, B.M. and Ross, J. (1987). Behavior in escalation situations: antecedents, prototypes, and solutions. In Cummings, L.L. and Staw, B.M. (eds), Research in Organization Behavior. Greenwich, CT: JAI Press.

Subramani, M.R. and Venkatraman, N. (2003). Safeguarding investments in asymmetric interorganizational relationships: theory and evidence. Academy of Management Journal, 46, pp. 46-62.

Sundaramurthy, C., Pukthuanthonh, K. and Kor, Y. (2014). Positive and negative synergies between the CEO's and the corporate board's human and social capital: a study of biotechnology firms. Strategic Management Journal, 35, pp. 845-868.

Tajfel, H. and Turner, J.C. (1979). An integrative theory of intergroup conflict. In Austin, W.G. and Worchel, S. (eds), The Social Psychology of Intergroup Relations. Monterey, CA: Brooks/Cole, pp. 33-47.

Tajfel, H. and Turner, J.C. (1986). The social identity theory of inter-group behavior. In Worchel, S. and Austin, L.W. (eds), Psychology of Intergroup Relations. Chicago, IL: Nelson-Hall, pp. 7-24.

Tjosvold, D. (1990). Team Organization: An Enduring Competitive Advantage. Chichester: Wiley.

Tsai, W. and Ghoshal, S. (1998). Social capital and value creation: the role of interfirm networks. Academy of Management Journal, 41, pp.464-476.

Tsoukas, H. (2003). Do we really understand tacit knowledge? In Easterby-Smith, M. and Lyles, M.A. (eds), The Blackwell Handbook of Organizational Learning and Knowledge Management. Oxford: Blackwell, pp. 410427.

Tura, T. and Harmaakorpi, V.(2005). Social capital in building regional innovative capability. Regional Studies, 39, pp. 1111-1125.

Uzzi, B. (1996). The sources and consequences of embeddedness for the economic performance of organisations: the network effect. American Sociological Review, 61, pp. 674-698.

Villena, V.H., Revilla, E. and Choi, T.Y. (2011). The dark side of buyer-supplier relationships: a social capital perspective. Journal of Operations Management, 29, pp. 561576.

Walker, G. (1985). Network position and cognition in a computer software firm. Administrative Science Quarterly, 30, pp. 103-130.

Warren, D.E., Dunfee, T.W. and Li, N. (2004). Social exchange in China: the double edged sword of guanxi. Journal of Business Ethics, 55, pp. 355372.

Wasserman, S. and Faust, K. (1994). Social Network Analysis: Methods and Applications. Cambridge: Cambridge University Press.

Weber, C. and Weber, B. (2011). Exploring the antecedents of social liabilities in CVC triads - A dynamic social network perspective. Journal of Business Venturing, 26, pp. 255272.

Weick, K.E. (1995). Sensemaking in Organizations. Thousand Oaks, CA: Sage.

West, M.A. (1996). Reflexivity and work group effectiveness: a conceptual integration. In West, M.A. (ed.), Handbook of Work Group Psychology. London: Wiley, pp. 555579.

Westlund, H. and Bolton, R. (2003). Local social capital and entrepreneurship. Small Business Economics, 21, pp. 77113.

Williamson, O.E. (1985). The Economic Institutions of Capitalism. New York, NY: Free Press.

Wood, R. and Bandura, A. (1989). Social cognitive theory of organizational management. Academy of Management Review, 14, pp. 361-384.

Woolcock, M. (1998). Social capital and economic development: toward a theoretical synthesis and policy framework. Theory and Society, 27, pp. 151-208.

Wright, G. and Goodwin, P. (1999). Future focused thinking: combining scenario planning with decision analysis. 
Journal of Multi-Criteria Decision Analysis, 8, pp. 311321.

Xiao, Z. and Tsui, A.S. (2007). When brokers may not work: the cultural contingency of social capital in Chinese high-tech firms. Administrative Science Quarterly, 52, pp. $1-31$.

Xiong, G. and Bharadwaj, S. (2011). Social capital of young technology firms and their IPO values: the complementary role of relevant absorptive capacity. Journal of Marketing, 75, pp. 87-104.

Yli-Renko, H., Autio E. and Sapienza, H.J. (2001). Social capital, knowledge acquisition, and knowledge exploitation in young, technology-based firms. Strategic Management Journal, 22, pp. 587613.
Yoo, T. and Lee, S.H. (2009). In search of social capital in state-activist capitalism: elite networks in France and Korea. Organization Studies 30, pp. 529-547.

Yu, Sui-Hua and Chiu, Wei-Ting (2010). Social capital and firm performance: the impact of technological uncertainty. SSRN Working Paper Series.

Zajac, E.J. and Bazerman, M.H. (1991). Blind spots in industry and competitor analysis: implications for interfirm (mis)perceptions for strategic decisions. Academy of Management Review, 16, pp. 3756.

Zheng, W. (2010). A social capital perspective of innovation from individuals to nations: where is empirical literature directing us? International Journal of Management Reviews, 12, pp. 151-183. 